ISSN (print): 1698-6180. ISSN (online): 1886-7995

www.ucm.es/info/estratig/journal.htm

Journal of Iberian Geology 38 (1) 2012: 9-30

http://dx.doi.org/10.5209/rev_JIGE.2012.v38.n1.39203

\title{
Active Tectonics of the Pyrenees: A review
}

\author{
Revisión de la tectónica activa de los Pirineos
}

\author{
P. Lacan ${ }^{1,2}$, M. Ortuño* 1,3 \\ ${ }^{1}$ Centro de Geociencias, Universidad Nacional Autónoma de México, \\ Blvd. Juriquilla, 3001, 76230, Juriquilla, Querétaro, Mexico \\ ${ }^{2}$ Laboratoire des Fluides Complexes et leurs Réservoirs (LFC-R) UMR5150 - CNRS, Université de Pau, \\ IPRA, BP 1155, F-64013 Pau Cedex, France \\ ${ }^{3}$ Departament de Geodinàmica i Geofisica, Universitat de Barcelona, Martí i Franquès s/n, 08028, Barcelona, Spain \\ *Corresponding author: maria_ortuno@geociencias.unam.mx. \\ Tel.: +52 (442) 238-1104 Ext. 104; fax: +52 (442) 238-1124
}

Received: 05/07/2011 / Accepted: 18/04/2012

\begin{abstract}
The Pyrenees have experienced at least seven earthquakes with magnitude $M>5$ in the last 400 years. During the last decades, several seismotectonic, neotectonic and paleoseismological studies have focused on identifying the main active structures of the areas experiencing damaging earthquakes. In spite of these studies, the regional stress regime is still discussed and there is no unequivocal seismotectonic model at the scale of the range. In this paper, we first present a revision of the former works on active faults in the Pyrenees, and then we discuss the main results in terms of their neotectonic setting. We have distinguished five neotectonic regions according to their seismicity, faulting style and morphologic evolution: the westernmost Pyrenees, the North Western Pyrenean zone, the Foreland basins, the Lower Thrust Sheets Domain and the Eastern Pyrenees. This review lead us to differentiate the range into two major domains: the High Chain, where active faults are controlled by vertical maximum stresses, and the Low Chain, where horizontal maximum stresses of variable orientation seem to be dominant. We propose that these different stress domains are related to the isostatic rebound in response to either the difference in crustal thickness and/or the distribution of the Plio-Quaternary erosion.
\end{abstract}

Keywords: Neotectonics, Seismogenetic sources, Stress field, Geodynamics, Isostatic compensation of erosion 


\section{Resumen}

En los últimos 400 años, los Pirineos han sufrido al menos siete terremotos de magnitud $\mathrm{M}>5$. Durante las últimas décadas, varios estudios de sismotectónica, neotectónica y paleosismología han tratado de identificar las principales estructuras activas en las zonas epicentrales de los terremotos destructivos. A pesar de estos estudios, el estado de esfuerzos sigue bajo debate, sin que haya un modelo sismotectónico unívoco a la escala de la cordillera. En este artículo, realizamos una revisión de los trabajos previos sobre fallas activas en los Pirineos, y comentamos los principales resultados en términos de su contexto neotectónico. Hemos distinguido cinco regiones neotectónicas de acuerdo con su evolución geomorfológica, su sismicidad y el estilo de sus fallas: los Pirineos más occidentales, la Zona Noroeste Pirenaica, las cuencas de antepais, el dominio de láminas cabalgantes inferiores y los Pirineos Orientales. Esta revisión nos ha llevado a diferenciar la cadena en dos dominios principales: la Alta Cadena, donde estructuras paralelas a la cordillera son reactivadas como fallas normales y la Baja Cadena, donde las fallas han sido reactivadas por esfuerzos máximos compresivos subhorizontales y de orientación variable. En este trabajo proponemos que las diferencias en los esfuerzos de estos dominios guardan relación con el reajuste isostático en respuesta a diferencias en el espesor de la corteza y/o la distribución de la erosión Plio-cuaternaria.

Palabras clave: Neotectónica, Fuentes sismogenéticas, Campo de esfuerzos, Geodinámica, Compensación isostática a la erosión

\section{Introduction}

Present-day plate convergence between Africa and Western Europe is mostly accommodated along the structures comprising the Betics-Alboran-Rif and Atlas domains. This motion has a main component oriented NNW-SSE to NW-SE and a rate of 4 to $6 \pm 0.5 \mathrm{~mm} /$ year (DeMets et al., 1994; Vernant et al., 2010, Billi et al., 2011). In the Pyrenees, the Present-day interplate velocity is certainly small, as attested by GPS measurements performed across the range over 10 years, which show uncertainties greater than the tectonic signal $(<1$ $\mathrm{mm} / \mathrm{yr}$, Nocquet and Calais, 2004; Asensio et al., 2012). In spite of this slow deformation rate, the Pyrenees exhibit continuous seismic activity and are the second most seismically area of the Iberian Peninsula and the main seismogenic region of continental France, as shown by its instrumental and historical seismicity (Fig. 1; Fig. 2; Souriau and Pauchet, 1998; Souriau et al., 2001; Rigo et al., 2005; Jiménez et al., 1999; Herraiz et al., 2000; Olivera et al., 2006).

Although moderate earthquakes characterize the instrumental record (Fig. 2), the historical seismicity (Fig. 1) is indicative of the seismogenic potential of the Pyrenean structures, with at least four great earthquakes (with magnitudes $\mathrm{M}=6-7$ ) during the last 650 years (E.g.: Vogt, 1979; Lambert et al., 1996; Olivera et al., 2006). These destructive events had MSK intensities between VIII and IX and the last one occurred in 1750 , more than 250 years ago. The absence of catastrophic earthquakes in the last century is reflected in the lack of social awareness of this hazard, and also in a scarcity of scientific research devoted to the thorough study of seismogenic structures.

The identification and characterization of potentially seismogenic faults in the Pyrenean landscape has to deal with specific challenges, as it is the absence of surface faulting associated to the events recorded in the last centuries (e.g. Fleta et al., 2001) and the poor preservation of neotectonic features in settings of high relief and low deformation rates (e.g. Ortuño, 2008; Lacan, 2008). Moreover, the assessment of the seismic risk in the range has to face the difficulties of being a political border, which is being partly solved through international efforts to share the geological data of potentially seismogenic structures (Paleosis project, Fleta and Goula, 1998) and seismic risk assessment and warning systems (e.g. SISPyr, Isard project, Secanell et al., 2008).

The seismic hazard maps proposed for the Pyrenean domain up to date (e.g. Dominique et al., 1998; Autran et al., 1998; Marin et al., 2004; Secanell et al., 2008; GarcíaMayordomo and Insua-Arévalo, 2011) are based on the seismicity distribution and on seismotectonic domains, without the consideration of the traces of the active faults determined by paleoseismological and/or geomorphological studies. Furthermore, no geodynamical model has been proposed so far to jointly explain the activity of the active faults of the range. The neotectonic indicators have been incorporated to the seismotectonic models only at a local scale (e.g.; Goula et al., 1999; Herraiz et al., 2000), which is probably the result of the scarcity of neotectonic studies and the lack of reviews focusing on this subject.

This paper searches 1) to summarize the potentially seismogenic faults previously identified in the Pyrenees, 2 ) to distinguish the neotectonic domains in which these structures are active and 3) to propose a geodynamical model explaining the co-existence of the active structures at a Pyrenean scale.

\section{Neotectonic framework}

The Pyrenean orogen results from the Iberian-Eurasian collision during the Mesozoic-Cenozoic alpine orogeny 
(Choukroune and ECORS, 1989). This collision involved the Paleozoic basement affected by the previous Variscan orogeny and Permo-Triassic, Mesozoic and Paleogene rocks (Fig. 1), only deformed by thin skinned tectonics (e.g. Muñoz, 2002). The decrease of the orogenic forces (i.e. the beginning of the post-orogenic period) is asynchronous, starting during the Middle Oligocene in the eastern part and during the Middle Miocene in the western area (e.g. Paquet and Mansy, 1992; Vergés, 1994; Teixell, 1996). The post-orogenic period is characterized by a relatively slow convergence (E.g.: Vergés, 1993; Meigs and Burbank, 1997; Beaumont et al., 2000; Fidalgo González, 2001; Sinclair et al., 2005) with the result that the tectonic activity is not among the main factors defining the macromorphology. Although the chain could be considered as an inactive orogen, its seismicity and the ongoing tectonic activity of some of its structures indicate that it still is a living system.

In most of the Pyrenees, the neotectonic period (i.e. the period with a state of stress prevailing up to Present) started after the main compressional episode, and thus, is equivalent to the "post-orogenic period" defined above. The only region showing evidence of two consecutive post-orogenic phases is the Eastern Pyrenees. There, the alpine structures were affected by the Neogene Mediterranean rifting, which gave rise to the formation of Neogene intramontane and marine basins (e.g. Juliá and Santanach, 1980; Cabrera et al., 1988; Roca, 1996; Gallart et al., 2001; Mauffret et al., 2001). During the Plio-Pleistocene times, some of the faults bounding the Neogene basins have been inverted (Philip et al., 1992; Arthaud and Pistre, 1993; Grellet et al., 1994; Goula et al., 1999), and thus, the neotectonic period started more recently than in other parts of the range.

\subsection{The stress state of the chain: a source of debate}

During the last decades, several researches have aimed to understand the present day stress state of the Pyrenees based on the instrumental seismicity (Souriau and Pauchet, 1998; Souriau et al., 2001; De Vicente et al., 2008; Olaiz et al., 2009; Chevrot et al., 2011, among others) and/or on the definition of the seismotectonic regions with seismic hazard purposes (Olivera et al., 1986; Souriau and Pauchet, 1998; Souriau et al., 2001; Marin et al., 2004; Ruiz et al., 2006a; Secanell et al., 2008; GarcíaMayordomo and Insua-Arévalo, 2011).

Focal solutions obtained show a great variety of results in similar oriented faults, in such a way that no homogeneous stress field could be calculated at a regional scale (Nicolas et al., 1990; Delouis et al., 1993; Souriau et al., 2001). The diversity of mechanisms could be owed to a real complexity of the tectonically active structures (Souriau et Pauchet, 1998; Souriau et al., 2001; Rigo et $a l ., 2005)$. In spite of this difficulty, integrated analysis of geological data and nodal solutions led Herraiz et al. (2000) to propose a dominant vertical maximum stress $\left(\sigma_{1}\right)$ with a minimum stress $\left(\sigma_{3}\right)$ parallel to the range. Using a similar approach, Goula et al. (1999) proposed a $\mathrm{N}-\mathrm{S}$ orientation of the maximum horizontal stress $\left(\sigma_{\mathrm{Hmax}}\right)$ for NE Iberia. More recently, determination of the focal mechanisms performed by De Vicente et al. (2008), Sylvander et al. (2008), Stich et al. (2010) and Chevrot et al. (2011) suggests an extensional stress regime for the Pyrenean range, or at least for its central part. Stich et al. (2010) consider that the updated moment tensor catalogue for NE Iberia is insufficient to establish the characteristics of faulting for this region. Recent GPS data performed during the last 3.5 years could also be compatible with a slow on-going extension perpendicular to the range $(0.0025 \pm 0.0005 \mathrm{~mm} / \mathrm{yr} / \mathrm{km}$, Asensio et al., 2012).

\section{Seismogenic structures in the Pyrenees}

Five seismogenetic domains can be identified in the Pyrenees on the basis of the published data relating 1) the distribution of the seismicity and the focal mechanisms obtained for some of the earthquakes, 2) the geodynamics of the neotectonic structures and 3) the morphological evolution of the area. These domains are: (1) the Westernmost Pyrenees, (2) the North Western Pyrenean zone, (3) the Foreland basins, (4) the Lower Thrust Sheets Domain and (5) the Eastern Pyrenees (inset in Fig. 3; Table 1). These regions roughly match with the seismotectonic domains distinguished by García-Mayordomo and InsuaArévalo (2011) and Secanell et al. (2008) (Table 2). In the following lines, we review each of these domains, paying special attention on the active tectonic structures identified up to date. We include a last section on induced seismicity.

\subsection{Westernmost Pyrenees (Basque Massifs and Navarran Pyrenees)}

Historical seismicity catalogs (Fig. 1) show a high density of low to moderate events at the Westernmost Pyrenees, whereas the instrumental seismicity presents several clusters, the most striking one around Iruña (or Pamplona) city (Fig. 2).

Ruiz et al., 2006a have focused on the instrumental seismicity of the area and identified an E-W band of seismicity along the Leiza Fault (structure 1 on Table 1 and Fig. 3), the southern limit of the Cinco Villas Massif within the Variscan Basque Massifs. The authors have 


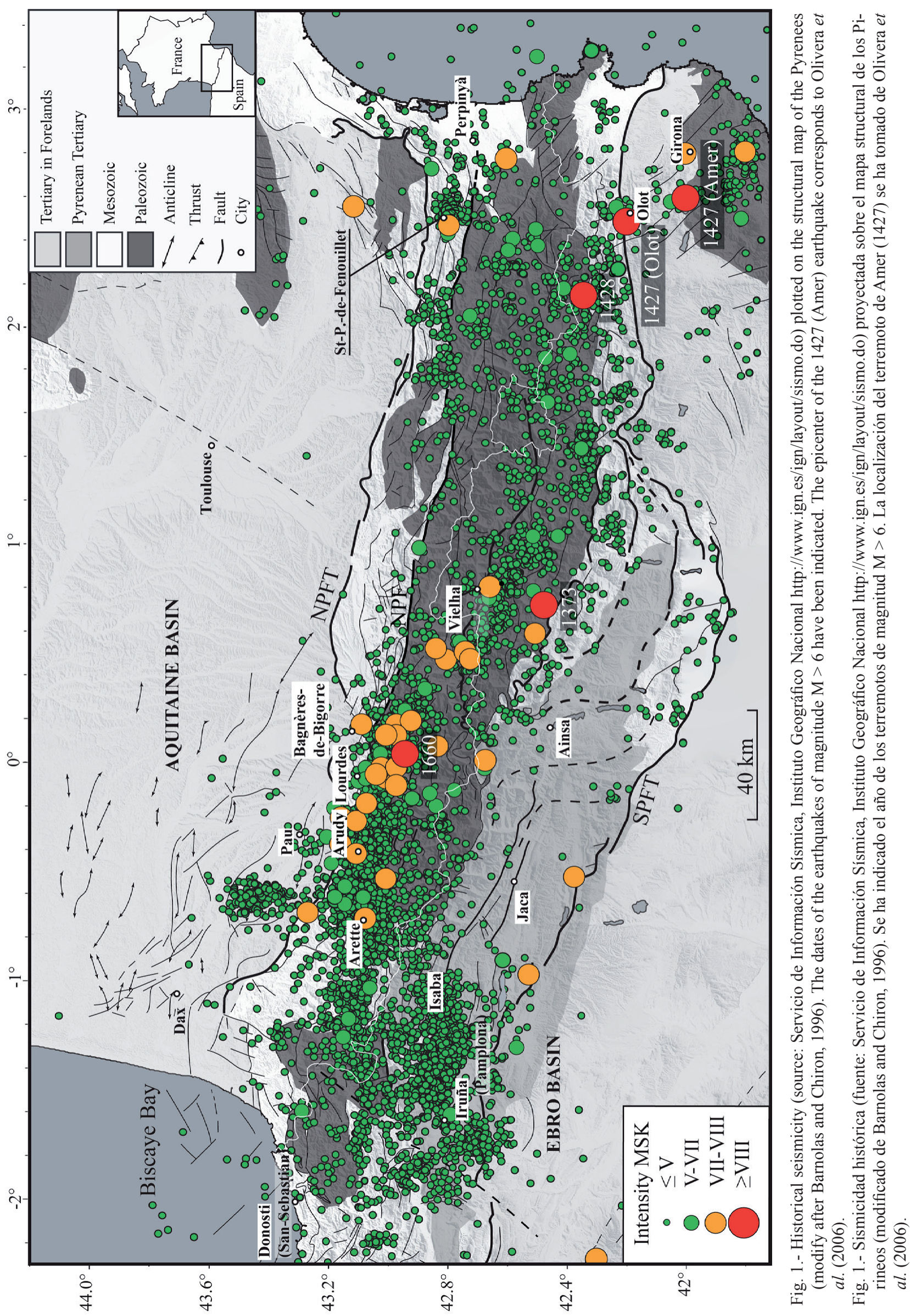


considered that the seismicity, which extends to the base of the seismogenic crust, is related to the activity of the Leiza Fault as a normal fault. To the south, other relevant seismic events are related to the central segment of the Pamplona Fault, and to different E-W thrust structures (Aralar Thrust, Roncesvalles Thrust; Ruiz et al., 2006a; structures 2, 3 and 4 on Table 1 and Fig. 3).

In this area, only the Leyre Fault (structure 5 in Table 1 and Fig. 3) has been reported as possibly having a geomorphological expression (Insua-Arévalo and García-Mayordomo, 2009; García-Mayordomo and Insua-Arévalo, 2011) but not conclusive work has been published to date. Baize et al. (2002) document tectonic deformation of fluvio-glacial deposits without clear relation with a known fault at Isaba, Roncal Valley, which according to the authors could as well result from glacialtectonics (site 6 on Table 2, Fig. 3).

Other references to neotectonic indicators at the Biscay coast are mentioned by Baize et al. (2002; and references therein). To date, these sites are poorly studied so they have not been included in this review.

\subsection{The North Western Pyrenean Zone}

The distribution of the historical and instrumental seismicity along the North Western Pyrenean Zone (NWPZ) singles this area out as the most seismically active of the Pyrenees (Fig. 1 and 2). The instrumental seismicity of the NWPZ clusters between the cities of Bagnères-deBigorre and Arette, in an $80 \mathrm{~km}$ long and $20 \mathrm{~km}$ wide area (Gagnepain-Beyneix et al., 1982; Souriau et al., 2001; Dubos, 2003; Rigo et al., 2005; Ruiz et al., 2006a; Dubos-Sallée et al., 2007). This E-W Pyrenean band of seismicity seems to be limited to the east by the Adour Fault (or Bigorre Fault, structure 7 on Table 1 and Fig. 3), which does not show any geomorphological expression (Souriau et al., 2001; Dubos, 2003; Dubos et al., 2004).

Three destructive earthquakes have struck this area in 1750 (Lourdes, I = VIII), 1967 (Arette, $\mathrm{M}=5.3$ - 5.7; according to Souriau et al., 2001) and 1980 (Arudy, Ml = 5.1; according to Gagnepain-Beyneix et al., 1982) (Fig. 1). The focal mechanism of the Arette earthquake corresponds to strike-slip (Trong and Rouland, 1971) or reverse faulting (MacKenzie, 1972). The main shock of the Arudy earthquake exhibits a right-lateral strike-slip component above an E-W trending nodal plane strongly dipping to the south (Nicolas et al., 1990). However, more recently, De Vicente et al. (2008) and Sylvander et al. (2008) considered an unpublished focal mechanism (Global Centroid-Moment-Tensor Project) that suggests normal faulting for the main shock of this event.
Several studies, mainly located in the Arudy epicentral area, have been performed to identify and characterize neotectonic structures in the NWPZ. Only a few structures show surface expression and the scarcity of field evidence makes it difficult to properly characterize the regional neotectonic activity.

\section{The Arudy epicentral area}

Using the location of the instrumental seismicity, anisotropic wavelets, structural analysis, or soil gas profiles, some authors have identified some fractures and surface faults possibly related to the Arudy earthquake aftershocks sequence (Darrozes et al., 1998; Gaillot et al., 2002; Baubron et al., 2002; Courjault-Radé et al., 2009). The interpretation of the identified surface faults allows to explain the extensional focal mechanism of some aftershocks in the transpressional regime $\left(\sigma_{\text {Hmax }}\right.$ oriented NW-SE) generally recognized in this area. (Rebaï et al., 1992; Delouis et al., 1993; Souriau and Pauchet, 1998; Souriau et al., 2001; Baubron et al., 2002; Rigo et al., 2005, among others). The faults and fractures identified are E-W to NW-SE oriented and less than $3 \mathrm{~km}$ long.

Also for this area and using seismological, structural and geomorphic data, Dubos-Sallée et al. (2007) proposed that the late Cretaceous inversion of the former Iberian Margin in a strike-slip mode resulted in a pop-up flower-like geometry limited to the south by the Mail Arrouy Thrust (structure 8 in Table 1, Fig. 3). This structure could correspond to the surface expression of the Herrère Fault (structure 9 in Table 1, Fig. 3), a buried crustal discontinuity reactivated as a right lateral fault in the present-day geodynamical arrangement. The authors consider that Herrère Fault could generate an earthquake with magnitude close to 6.5 based on its length (Table 3 ). The folding of late Pleistocene alluvial terraces formed on top of the Mail Arrouy Thrust indicates the recent activity of this fault as a reverse structure and supports the activity of the Herrère Fault in a strike-slip mode resulting from NE-SW horizontal compression (Lacan, 2008; Lacan et al., 2012; Nivière et al., submitted). Other possible indications of reverse faulting based on topographical anomalies of alluvial terraces have been reported in this zone of the Pyrenees (Pailhé and Thomas, 1984; Thomas and Pailhe, 1984; Delfaud et al., 1985). We have not included these reports in the inventory of surface ruptures due to the lack of detailed descriptions published up to date.

\section{The Lourdes Fault}

Alasset and Meghraoui (2005) have identified an eastwest-trending $50 \mathrm{~m}$ high fault scarp between the city of 


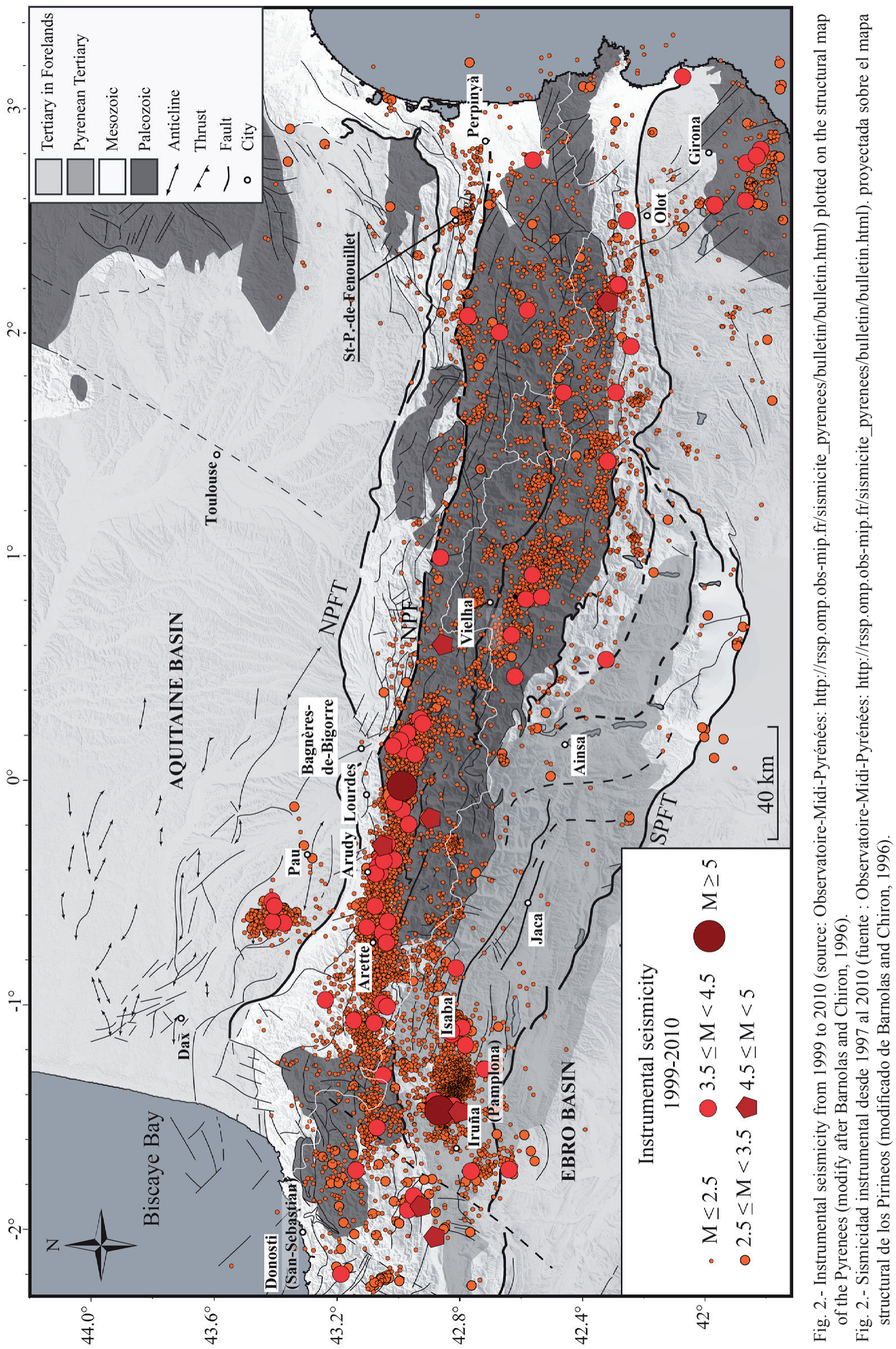


Lourdes and Arette that they interpreted as the Lourdes reverse fault trace (structure 10 on Table 1 and Fig. 3). This fault has a $50 \mathrm{~km}$ long trace and is made of three contiguous linear segments. Trenches across the eastern segment exhibit a normal contact between Mesozoic cover rocks and Quaternary alluvium that is interpreted as the surface expression of the Lourdes fault (blind reverse fault). According to these authors, the most recent faulting event would have occurred between $4221 \mathrm{BC}$ and 2918 BC. Fault parameters and paleoseismic results have led the authors to conclude that the Lourdes Fault and related sub-segments may produce $\mathrm{M}_{\mathrm{W}} 6.5$ to 7.1 earthquakes. The structural significance of the western segment of this fault is contested by Lacan et al. (2012).

\subsection{The foreland basins}

The Aquitaine and the Ebro basins are the major foreland basins of the Pyrenean range (Fig. 1). Their geology is characterized by low angle detachment structures that were inverted as thrust faults during the last episode of the orogenic compression (e.g. Jones, 2004; Teixell, 1996). Although these areas present low and sparse seismicity, deformation of Quaternary sediments has been reported at several locations, both at the Western Aquitaine and the North-eastern Ebro basins. In all cases, the setting of the deformation seems related to the growth of antiforms controlled by salt tectonics (halogenetic processes).

\section{The Audignon and Campagne anticlines}

Two sites described in the literature (structures 11 and 12 on Table 1; Fig. 3) show folding and faulting of Quaternary sediments in the Western Aquitaine basin: 1) the folding and reverse faulting of fluvio-glacial deposits located in the southern limb of the Audignon Anticline, at Horsarrieu (Thibault, 1969; Baize et al., 2002). The E-W to WNW-ESE orientation of the structures is parallel to the axis of the main anticline. This deformation is accompanied by injection of material from lower stratigraphic levels. According to Thibault (1969) and Baize et al. (2002), the deformation might be in part controlled by salt tectonics observed in the region; 2) oblique reverse and left lateral faulting of Quaternary interglacial fluvial sediments on top of the Campagne Anticline, at Mielhan. Also here, the orientation of the structures approximates the E-W strike of the anticline axis. The growth of the anticline seems to have uplifted fluvial terraces up to $40 \mathrm{~m}$ over the present day drainage level (Carbon et al., 1995; Baize et al., 2002). The study of a paleoseismological trench located in the younger succession showed the record of at least one paleoearthquake occurred $<500$ ka ago, which vertically displaced the fluvial layers by $1.40 \mathrm{~m}$ along an array of 11 faults and caused fractures on pebbles (Carbon et al., 1995). According to the authors, the faults probably are the surface expression of an active blind fault dipping to the south. Such a fault would be part of the detachment faults associated to the Aquitanian propagation front of the Pyrenean orogen. In this paper, we considered that the fractured pebbles next to the faults attest for the seismic origin of the deformation. Since the region is characterized by extensive growing of salt diapirs (Thibault, 1969 and references therein), we recommend considering the possibility of salt-tectonics as a second factor controlling the deformation.

For the Audignon and the Campagne anticlines, the evidence of active tectonics seem related to the reactivation of Pyrenean foreland detachment structures parallel to the range and under a NE-SW compression (Baize et al., 2002 and references therein). However the influence of salt tectonics can not be excluded.

\section{Canelles, Balaguer and Callús anticlines}

At the Central South Pyrenees, Grellet et al. (1994; and references therein) and Goula et al. (1999), report tectonic deformation of Plio-Quaternary alluvial deposits at several sites, without identifying any major fault associated to it. The sites are all located near the South Pyrenean frontal thrust (structures 13, 14 and 15 in Table 1 and Fig. 3), the boundary between the Ebro foreland basin and the Mesozoic (alloctonous) cover. The faulting affects, in all cases, Plio-Quaternary fluvial deposits located in the flanks of anticlines. Goula et al. (1999) analyses the deformation observed at Canelles (next to Canelles Diapir), Ager (at the flanks of the Balaguer Anticline), and Callús (on the Callús Anticline). The neotectonic origin of these features is not unequivocal and a possible halogenic component of such deformation needs to be taken into account due to their location with respect to anticlinal structures with salt nuclei.

\subsection{The Lower Thrust Sheets Domain (LTSD)}

The "lower thrust sheets" is the structural term proposed by Muñoz (1992) to define the antiformal stack made of Paleozoic rocks in the core of the Pyrenean range. This area is part of the wider term "Axial zone" classically used in the division of the Pyrenees. All the active faults reported in this domain are active as normal faults.

\section{Faults in the Western LTSD}

The seismicity along the North-Western Pyrenean zone (Fig. 2) is organised, at its southern part, in several clus- 


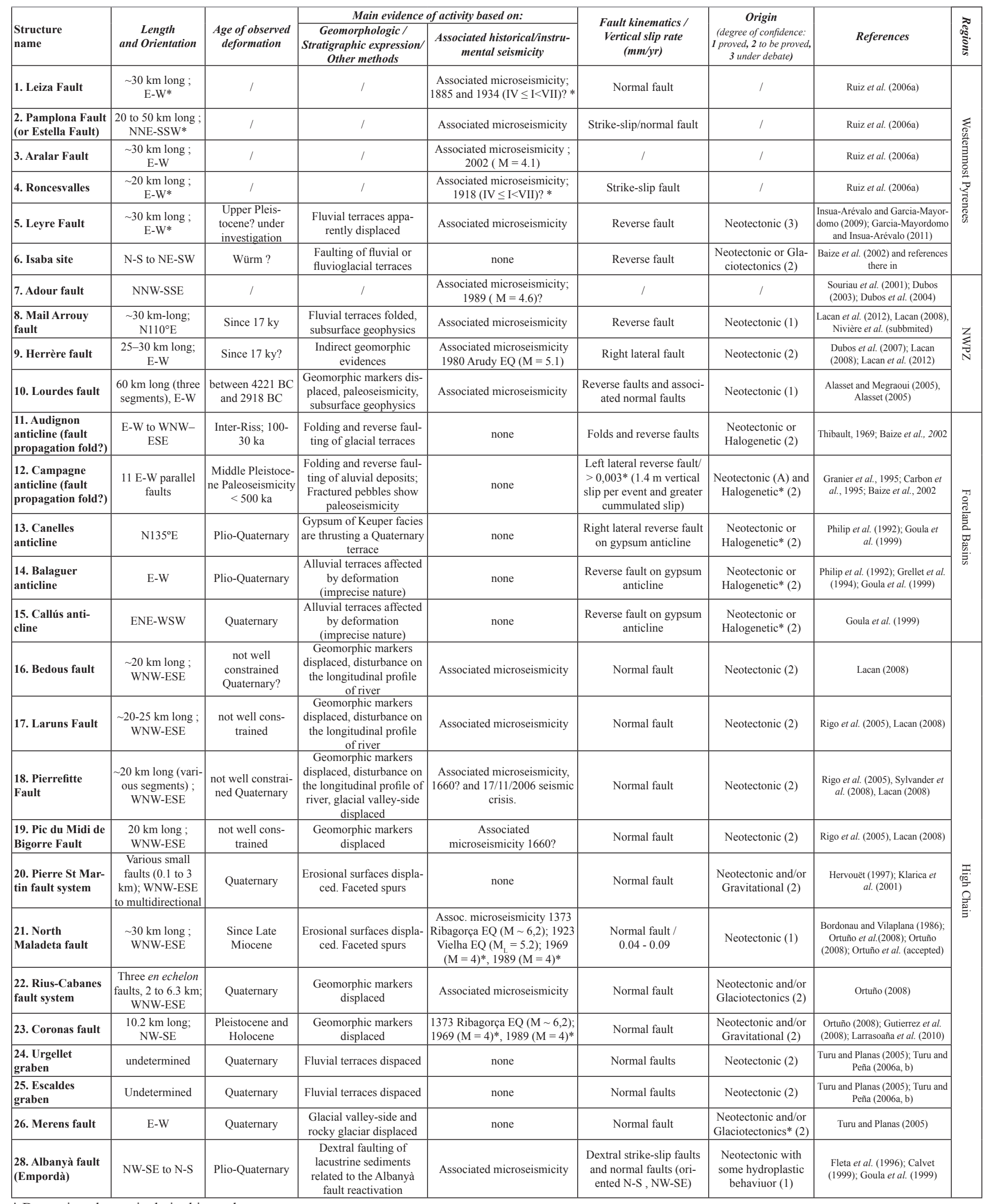

* Data asigned tentatively in this work

Table 1.- Summary of the published neotectonic data of the main active structures considered as possibly seismogenetic in this study.

Table 1.- Resumen de los datos neotectónicos publicados acerca de las principales estructuras activas consideradas como posibles fuentes sismogenéticas en este estudio. 


\begin{tabular}{|c|c|c|c|c|c|c|c|c|}
\hline \multirow[b]{2}{*}{$\begin{array}{l}\text { Structure } \\
\text { name }\end{array}$} & \multirow[b]{2}{*}{$\begin{array}{l}\text { Length } \\
\text { and Orientation }\end{array}$} & \multirow[b]{2}{*}{$\begin{array}{l}\text { Age of observed } \\
\text { deformation }\end{array}$} & \multicolumn{2}{|c|}{\begin{tabular}{|l|} 
Main evidence of activity based on: \\
\end{tabular}} & \multirow[b]{2}{*}{$\begin{array}{c}\text { Fault kinematics / } \\
\text { Vertical slip rate } \\
(\mathrm{mm} / \mathrm{yr})\end{array}$} & \multirow{2}{*}{\begin{tabular}{|c|} 
Origin \\
(degree of confidence: \\
1 proved, 2 to be proved, \\
3 under debate) \\
\end{tabular}} & \multirow[b]{2}{*}{ References } & \multirow[b]{2}{*}{ ?ี } \\
\hline & & & \begin{tabular}{|c|} 
Geomorphologic/ \\
Stratigraphic expression/ \\
Other methods \\
\end{tabular} & $\begin{array}{l}\text { Associated historical/instru- } \\
\text { mental seismicity }\end{array}$ & & & & \\
\hline $\begin{array}{l}\text { 28. Albanyà fault } \\
\text { (Empordà) }\end{array}$ & NW-SE to N-S & Plio-Quaternary & $\begin{array}{c}\text { Dextral faulting of } \\
\text { lacustrine sediments } \\
\text { related to the Albanyà } \\
\text { fault reactivation }\end{array}$ & Associated microseismicity & $\begin{array}{l}\text { Dextral strike-slip faults } \\
\text { and normal faults (ori- } \\
\text { ented N-S , NW-SE) }\end{array}$ & $\begin{array}{l}\text { Neotectonic with } \\
\text { some hydroplastic } \\
\text { behaviuor (1) }\end{array}$ & $\begin{array}{l}\text { Fleta et al. (1996); Calvet } \\
\text { (1999); Goula et al. (1999) }\end{array}$ & \multirow{7}{*}{ 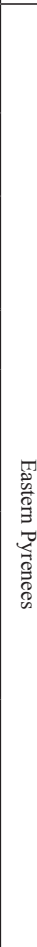 } \\
\hline \multirow[b]{2}{*}{$\begin{array}{l}\text { 29. Tech fault } \\
\text { system (Alberes) }\end{array}$} & $\begin{array}{c}20 \text { km long; ENE- } \\
\text { WSW } 1.6 \mathrm{~km} \\
\text { vertical slip } \\
\end{array}$ & $\begin{array}{l}\text { Since Miocene } \\
\text { (a) /Miocene- } \\
\text { Pliocene (b) } \\
\end{array}$ & $\begin{array}{c}\text { Faceted spurs and defor- } \\
\text { mation of Miocene and } \\
\text { Pliocene stratta } \\
\end{array}$ & \multirow[b]{2}{*}{ none } & $\begin{array}{l}\text { Normal fault / } 0.1 \text { since } \\
\text { Late Miocene (b) }\end{array}$ & Neotectonic (1) & $\begin{array}{l}\text { a) Brias et al. (1990); b) Calvet } \\
\quad(1985 ; 1999)\end{array}$ & \\
\hline & $\begin{array}{l}\text { NE-SW Maurei- } \\
\text { llas fault/E-W } \\
\text { Montesquieu fault }\end{array}$ & Quaternary & $\begin{array}{c}\text { Geomorphic markers } \\
\text { displaced (a); Miocene } \\
\text { and Quaternary (a) levels } \\
\text { deformed }\end{array}$ & & $\begin{array}{l}\text { Strike-slip and Reverse } \\
\text { faults }\end{array}$ & Neotectonic (1) & $\begin{array}{c}\text { a) Grellet et al. (1994); Calvet } \\
\text { (1999); Goula et al. (1999); } \\
\text { Fleta and Goula 1998; GEOTER } \\
\text { (1999) }\end{array}$ & \\
\hline 30. Capçir basin & $\sim 7$ km-long; N-S & Plio-Quaternary & Faceted spurs (b) & Associated microseismicity & Normal fault & Neotectonic (2) & $\begin{array}{c}\text { (a) Calvet (1999) (b) Briais et } \\
\text { al. (1990) }\end{array}$ & \\
\hline $\begin{array}{l}\text { 31. Cerdanya fault } \\
\text { (SW southern Têt } \\
\text { Fault) }\end{array}$ & $\begin{array}{l}\sim 40 \mathrm{~km} \text { long; } \\
\text { NE-SW. Activ- } \\
\text { ity observed in } \\
\text { secondary faults } \\
\text { within the graben }\end{array}$ & Late Quaternary & $\begin{array}{l}\text { Quaternary sediments } \\
\text { thrusted on related faults }\end{array}$ & $\begin{array}{c}\begin{array}{c}\text { Associated microseismicity } \\
(\mathrm{e}) ; 1970(\mathrm{Ml}=4,9 ; \mathrm{Ml}=4.7) \\
1988(\mathrm{M}=3.8)^{*}\end{array}\end{array}$ & Reverse fault & $\begin{array}{c}\text { Neotectonic (a-c) } \\
\text { and/or Gravitational } \\
\text { (d) (3) }\end{array}$ & $\begin{array}{c}\text { a) Philip et al. (1992); b) Calvet } \\
\text { (1999); c) Goula } \text { et al. (1999); d) } \\
\text { Baize et al. (2002); e) Souriau } \\
\text { and Pauchet (1998); Carozza } \\
\text { and Baize (2004) }\end{array}$ & \\
\hline $\begin{array}{l}\text { 32. Conflent fault } \\
\text { (NE southern Têt } \\
\text { Fault) }\end{array}$ & $\begin{array}{c}40 \mathrm{~km} \text { long; SSW- } \\
\mathrm{NNE} ; 2-3 \mathrm{~km} \\
\text { vertical slip (a) }\end{array}$ & $\begin{array}{l}\text { Plio-Quaternary/ } \\
\text { Inactive }(a, g, h)\end{array}$ & $\begin{array}{l}\text { Deformation of Pliocene } \\
\text { sediments/Exhumed } \\
\text { faceted spurs }\end{array}$ & Associated microseismicity (c) & Sinistral strike-slip (d) & Neotectonic (3) & $\begin{array}{l}\text { a) Calvet (1985; 1999); b) Philip } \\
\text { et al. (1992); c) Souriau and } \\
\text { Pauchet (1998); d) Carozza and } \\
\text { Delcaillau (2000); e) Carozza } \\
\text { and Baize (2004); f) Maurel et } \\
\text { al., 2008 g) Petit and Mouthe- } \\
\text { teau (2011); h) Neopal (2012) }\end{array}$ & \\
\hline $\begin{array}{l}\text { 33. Northern Têt } \\
\text { fault }\end{array}$ & $\begin{array}{l}30 \mathrm{~km} \text { long (b); } \\
\text { SSW-NNE; } 0.3 \\
-0.15 \mathrm{~km} \text { during } \\
\text { Pliocene (b) }\end{array}$ & $\begin{array}{c}\text { Since Oligocene } \\
\text { to - Early Pliocene } \\
\text { (c, d)/From Early } \\
\text { to Late Pliocene } \\
\text { with exception of } \\
\text { the southernmost } \\
\text { segment, possibly } \\
\text { active during the } \\
\text { Pleistocene (b) }\end{array}$ & $\begin{array}{l}\text { Faceted spurs (exhumed) } \\
\text { and basin-fluvial mor- } \\
\text { phometry (b); Pliocene } \\
\text { sediments deformed }\end{array}$ & Associated microseismicity & $\begin{array}{c}\text { Oblique reverse-sinistral } \\
\text { strike slip fault (a and c); } \\
\text { Normal and left-lateral } \\
\text { fault (b) }\end{array}$ & Neotectonic (3) & $\begin{array}{c}\text { a) Goula et al., 1999; b) } \\
\text { Delcaillau et al. (2004) c) Calvet } \\
\text { (1996; 1999);d) Carroza and } \\
\text { Baize (2004) }\end{array}$ & \\
\hline
\end{tabular}

* Data asigned tentatively in this work

Table 1.- Continuation

Table 1.- Continuación

ters. These clusters are located to the south of the North Pyrenean Fault (NPF) and within the Western LTSD, and seem to be arranged (according to Rigo et al., 2005) in three deep-event-limiting surfaces dipping to the north with NW-SE to E-W strikes. Lacan (2008) proposed a correlation of these surfaces with four WNW-ESE faults displayed "en echelon" and named Bedous, Laruns, Pierrefitte and Pic du Midi du Bigorre Faults (structures 16 to 19 on Table 1 and Fig. 3). These faults are located at the northern limit of the Western LTSD and correspond, in most cases, to the traces of alpine thrusts reactivated as normal faults during the post-orogenic period. They seem to have partly controlled the Quaternary erosion and sedimentation distribution; the faults separate smoothy reliefs to the north, where the valleys are filled with Quaternary sediments, from sharply incised reliefs to the south, which result from strong Quaternary erosion. Topographic steps observed along the longitudinal profiles of the rivers crossing the fault traces are ascribed to the recent activity of each of these faults (Lacan, 2008) The Pierrefitte Fault has been considered as the most probable seismogenic source of the 2006 seismic crises (Lacan, 2008). The main evidence is the on-depth location of the main shock and of more than 250 aftershocks proposed by Sylvander et al. (2008).
Even though the Bedous, Laruns, Pierrefitte and Pic du Midi du Bigorre Faults present some indirect signs of Quaternary tectonic activity, available geomorphological evidence are insufficient to demonstrate and quantify their Quaternary activity.

To the south of the Bedous Fault, a group of small WNW-ESE normal faults displacing the glacial surfaces of the Pierre-Saint-Martin Massif have been described as faults that might result from gravity forces (structure 20 on Table 1 and Fig. 3; Hervouët, 1997; Klarica et al., 2001). According to Lacan (2008), such a gravitational movement could be related to the activity of the Bedous Fault.

\section{Faults in the Central LTSD (Maladeta Massif and Andorra).}

Olivera and Fleta (1996) and Souriau and Pauchet (1998) have noticed a NW-SE oriented and deep cluster of instrumental seismicity in the Maladeta Massif region. Olivera and Fleta (1996) identified a shallower zone with a maximum depth of $6 \mathrm{~km}$ around the epicentre of the Vielha earthquake (1923, ML = 5.2; Susagna et al., 1994). In this region, Bordonau and Vilaplana (1986) ascribed for the first time Quaternary activity to the North Maladeta Fault in this area. More recently, Ortuño (2008) 


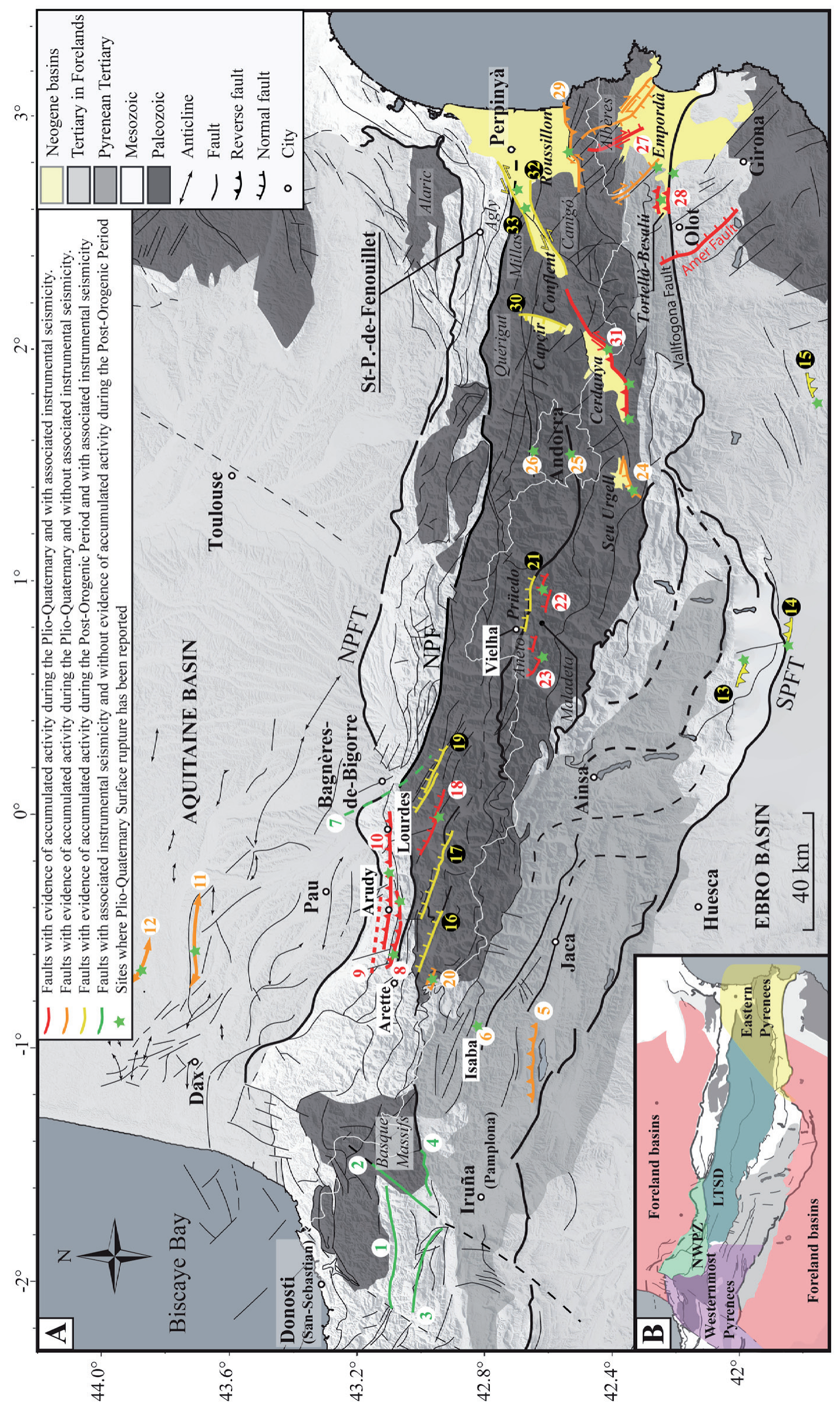

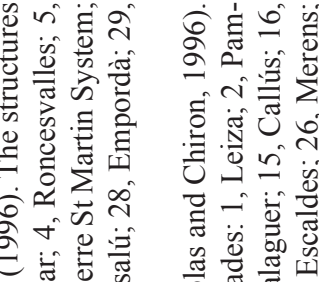

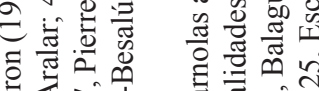

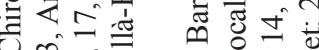

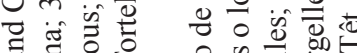

ब

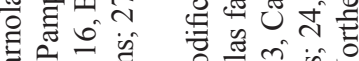

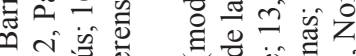

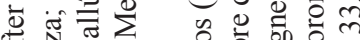

ज्ञ

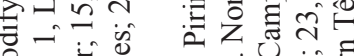

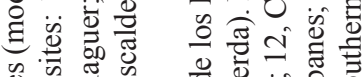

बैं क्ष

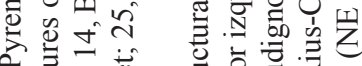

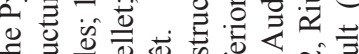

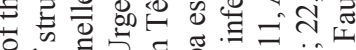

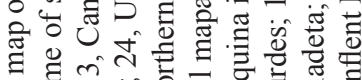

च

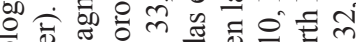

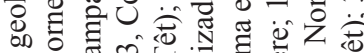

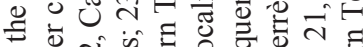

б

过

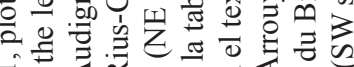

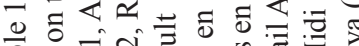

诺

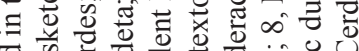

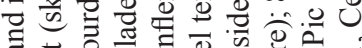

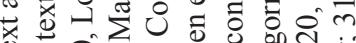

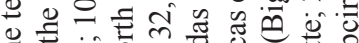

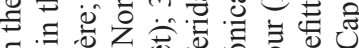

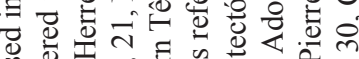

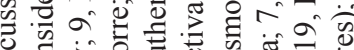

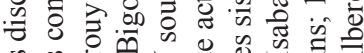

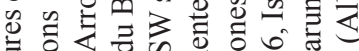

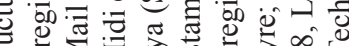

क.

०००ण के

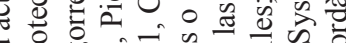

包 N

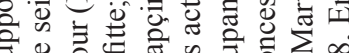

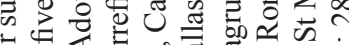

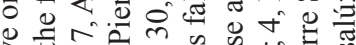

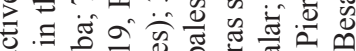

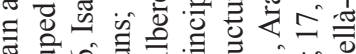

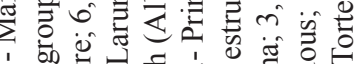

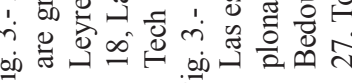




\begin{tabular}{|c|l|c|l|}
\hline \multicolumn{1}{|c|}{ Region } & $\begin{array}{c}\text { Number of structures } \\
\text { with surface } \\
\text { expression }\end{array}$ & $\begin{array}{c}\text { Corresponding Seismotectonic region of García-Mayordomo and } \\
\text { Insua-Arévalo (2011)/Secanell et al. (2008) }\end{array}$ \\
\hline 1 & Westernmost Pyrenees & $2^{*}$ & 7 (Pamplona) and 8 (Lumbier) $/ 5$ \\
\hline 2 & North Western Pyrenean Zone & 2 & 2 (North Pyrenean region, central part)/part of 7 \\
\hline 3 & Foreland basins & 2 & 1 (North Pyrenean region, western part)/6 \\
\hline & Western Aquitanian & 2 & 10 (South Pyrenean region, Graus)/5 \\
\hline & North-Central Ebro & 9 & 5 and 6 (Western and Central Axial Pyrenees)/part of 7 and 8 \\
\hline 4 & Western Central High Chain & 6 & not considered/4 \\
\hline 5 & Eastern Pyrenees & & \\
\hline
\end{tabular}

* not conclusive works performed

Table 2.- Correlation between the five seismotectonic regions distinguished in the text and those considered by Secanell et al. (2008) and García-Mayordomo and Insua-Arévalo (2010).

Table 2.- Correlación entre las cinco regiones sismotectónicas diferenciadas en el texto y las consideradas por Secanell et al. (2008) y García-Mayordomo y Insua-Arévalo (2010).

and Ortuño et al. (2008; accepted) have identified and characterized several possible seismogenic faults by multiproxy analyses combining macroseismological, geomorphological, structural, paleoenvironmental and subsurface geophysical data. The North Maladeta Fault (fault 21 on Table 1 and Fig. 3) is a WNW-ESE normal fault that offset the remnants of a pre-Late Miocene peneplain, giving place to the formation of the Prüedo neotectonic basin. The central part of this structure has been considered the most probable source of the Vielha earthquake. Ortuño et al. (accepted) have provided data on the late Miocene paleoelevation of this area and single out the North Maladeta Fault as the structure accomodating the differences in recent exhumation recorded at the downthrown and upthrown blocks.

To the south of the North Maladeta Fault, the WNWESE Rius-Cabanes system displays three normal faults en echelon (structure 22 on Table 1 and Fig. 3). These faults displace the glacial surfaces of the Maladeta Massif, and have lengths that range from 2 to $6.3 \mathrm{~km}$. According to Ortuño (2008), they could be responsible of the cluster in seismicity detected by Olivera et al. (1994). At the south-western continuation of the North Maladeta Fault, the NW-SE oriented Coronas Fault (structure 23 on Table 1 and Fig. 3) shows evidence of neotectonic activity, as it is the displacement of the southern slope of the Aneto Massif (Ortuño, 2008). Hydrologic alterations (Larrasoaña et al., 2010) as well as the repeated gravitational sliding (Gutierrez et al., 2008) in the area may also be consequences of the paleoseismic activity of the Coronas Fault.

The location of all the former faults within the area of epicentral uncertainty of the Ribagorça earthquake (1373, $\mathrm{M}_{\mathrm{W}}=6.2 \pm 0.5$; Olivera et al., 2006) leads to consider all of them as possible seismogenic sources of this event (Ortuño, 2008).

To the East, in the headwaters of the Segre River, Turu and Planas (2005) and Turu and Peña $(2006 a, b)$ report Quaternary faulting of fluvial terraces located at the Urgellet and the Escaldes grabens (structures 24 and 25 on Table 1 and Fig. 3), interpreted as possible neotectonic features among other features described in the region. Turu and Planas (2005) also report recent activity on the E-W oriented Merens Fault (structure 26 on Table 1 and Fig. 3), which seems to vertically displace rocky glaciers originated during the Last Glacial Period. The location of this fault with respect to the glacial valley suggests that it could be related to glacial rebound processes, according to the criteria proposed by Ortuño $(2008,2009)$. Not detailed research has been published so far relating these structures.

\subsection{The Easternmost Pyrenees}

The instrumental seismicity at the eastern end of the range is moderate and relatively sparse (Fig. 1 and 2), but some of the most damaging earthquakes in the historical catalogue, the Middle Age seismic crisis of 1427 - 1428 (Olivera et al., 2006), took place in this region. Souriau and Pauchet (1998) identify several zones where the instrumental seismicity concentrates: a cluster around the Garrotxa volcanic field (around Olot town), an alignment along the northern boundary of the Empordà Basin (structures 27 on Table 1 and Fig. 3), and an alignment along the NE prolongation of the northern Têt Fault (structure 28 on Table 1 and Fig. 3) and parallel structures within the Agly Massif (Figs. 2, 3). 
This domain has experienced tens of $M \geq 4$ events during the instrumental period, some of which have been studied by Gallart et al. (1982), Olivera et al. (1996) and Rigo et al. (1997), among others. The inversion analysis of 18 focal mechanisms (11 of them located at the Eastern Pyrenees) obtained for NE Iberia by Goula et al. (1999) has led the authors to propose an horizontal N-S main stress for this region, but has not allow them to determine orientation of the minimum stress. For the Saint Paul de Fenouillet event (18/02/1996; $\mathrm{M}=5.2)$, Rigo et al. (1997) and Pauchet et al. (1999) obtain a focal mechanism indicating dextral slip along ENE-WSW to E-W oriented faults, compatible with a $\mathrm{N} 030^{\circ} \mathrm{E}$ compression.

The Eastern Pyrenees was affected by the Neogene Mediterranean rifting, geodynamical episode that spread out through a wide region of Western Europe. The extension that reached the easternmost Pyrenees also affected neighbouring regions as its transition to the Alps (Languedoc-Provence Region, also affected by the Massif Central geodynamical evolution) and the Catalan Coastal Ranges. In this paper, we have not included potentially seismogenic structures located out of the Pyrenean domain, as those of the Gulf of Lion and Languedoc-Provence region (e.g. Mazamet Fault) or the Catalan Coastal Ranges (faults in the Vallès-Penedès) neither the Amer Fault (Fig. 3) (Perea et al., 2012).

\section{Faults in the Empordà Basin}

The Empordà Basin is dissected by E-W to N-S faults which show Plio-Quaternary activity, as reported by Philip et al. (1992), Fleta et al. (1996), Calvet (1999) and Goula et al. (1999), among others. These authors report Plio-Quaternary faulting related to the E-W reverse faults bounding the Tortellà-Besalú Basin (structure 27 on Table 1 and Fig. 3) and its continuation within the Empordà Basin, structures related to the reactivation of the Vallfogona alpine thrust (Fig. 3). Additionally, some of the N-S to NW-SE Neogene faults in the area have been reactivated with a dominant dextral component during the Plio-Quaternary. The Incarcal outcrop, associated to the Albanyà Fault (structure 28 on Table 1 and Fig. 3) shows hydroplastic structures in faulted vertebrates of Plio-Quaternary age, interpreted as possible coseismic and synsedimentary features by Calvet (1999), among others. The existence of a halogenesis and karstification obscures the pure neotectonic origin of these structures (Calvet, 1999).

\section{The Tech Fault System}

The ENE-WSW oriented Tech Fault bound the Rosselló Basin to the south. This basin is the northern limit of the Alberes Massif. The Tech Fault (structure 29 on Table 1 and Fig. 3) was characterized by normal faulting during the Oligo-Miocene extension and at the Pliocene (Calvet, 1985; 1999; Briais et al., 1990). Briais et al. (1990) have classified the Tech fault as an active normal fault based on its geomorphological expression. The post-Pliocene activity of some of its segments as a compressive structure reported by Calvet (1985; 1999), Grellet et al. (1994), and Goula et al. (1999) suggests that the geomorphic features analysed by Briais et al. (1990) are inherited from the previous extensional period.

Goula et al. (1999) describe the deformation of Miocene deposits by the Montesquieu segment, an E-W reverse fault dipping to the south, and to the Maureillas Segment, a NE-SW strike-slip fault that displaces the trace of the Tech main fault. Calvet (1999) also identifies deformation on Quaternary river terraces at these sites.

To the south of the Tech Fault, Calvet (1985) reports the activity of vertical NNW-SSE faults displacing old peneplains within the Alberes Massif. To the north fault, within the Rosselló basin, Goula et al. (1999) report normal faulting of upper Pliocene deposits by a NNE-SSW fault, with no major morphostructural feature associated to it (Fig. 3).

\section{The Têt (Cerdanya-Conflent) fault system}

The main faults identified in the easternmost Pyrenees are part of a NE-SW oriented system that extends along $\sim 120 \mathrm{~km}$ and is composed of three distinctive segments: a) the Cerdanya Fault (or SW southern Têt Fault), which dips to the NW and bounds the Cerdanya Semigraben to the SE, b) the Conflent Fault (or NE southern Têt), which dips to the NW and bounds the Conflent Graben to the SE and c) the northern Têt Fault (or Prades-Ille sur Tèt Fault), which dips to the S-SE and separates the ConfletRousillon Graben and the Agly Massif (Fig. 3). Some of the authors dealing with these fault segments consider a) and b) (e.g. Briais et al., 1990) or b) and c) (e.g. Carozza and Delcaillau, 2000) as two parts of a single fault system.

The tectonic activity of these structures as normal faults extends from the Miocene until the Late Pliocene (Cabrera et al., 1988; Roca, 1996; Pous et al., 1996; Carozza, 1998; Calvet, 1999; Calvet and Gunnell, 2008, among others). The activity of the fault system during the PlioQuaternary has been under debate. Briais et al. (1990) have supported that the fault system is still active as a pure extensional structure, mainly based on its geomorphological expression. More recent researches (commented below) have shown that this expression does not correspond to the recent activity of the fault system, 
supporting the inactivity of some of its segments and/or reporting the Plio-Quaternary activity as reverse and sinistral strike slip faults of other segments. Both the reverse and strike slip dynamics of the Têt Fault system are explained by an N-NE compressional regime (e.g. Grellet et al., 1994; Calvet, 1999; Goula et al., 1999; Herraiz et al., 2000, Carozza and Delcaillau, 2000) following the Neogene extension at this part of the range. To the north of the Cerdanya Semigraben, the Capçir Basin (structure 30 on Table 1 and Fig. 3 ) is also bounded to the east by a N-S Neogene fault (Calvet, 1999), still active during the Quaternary according to Briais et al. (1990).

For Goula et al. (1999), the Cerdanya-Conflent Ba$\sin$ is the westernmost region affected by the Neogene Mediterranean rifting. Quaternary evidence of reverse faulting of the south-westernmost segment, the Cerdanya Fault (structure 31 on Table 1 and 2; Fig. 3), has been described by Philip et al. (1992), Calvet (1999) and Goula et al. (1999). These authors document deformations of Pleistocene fluvial terraces of the Segre River (at Estavar) by a WNW-ESE reverse fault oblique to the main fault system. Baize et al. (2002) reported more than 2 $\mathrm{m}$ of along-dip displacement of Miocene deposits thrusted over Pleistocene fluvial sediments, as observed in a trench perpendicular to the fault. The gravitational origin of this deformation, excluded by Calvet (1999), is considered feasible by Baize et al. (2002). Two other indicators of active tectonics are reported by Grellet et al. (1994) on faults oblique to the main Cerdanya Fault: a) the reverse faulting of the Miocene sequence along the SW termination of the fault and b) the normal faulting of Late Quaternary fluvial sediments by N010E oriented faults at Ossejà (secondary faults at the Cerdanya Fault northern termination). Baize et al. (2002) interpret this latter outcrop as a natural fluvial feature and reject it as a neotectonic feature.

Goula et al. (1999), Baize et al. (2002) locate two macroseismic events occurring in $1970(\mathrm{M}=4.9 ; 5 / 4)$ and $(\mathrm{M}$ $=4.7 ; 13 / 4)$ in the Cerdanya Basin, whereas other macroseismic events are located at the SW continuation of the fault $(M=3.6 ; 20 / 02 / 1988)$ and at the SE block $(M=4.5$; 19/03/1992;). The maximum intensities of several historical earthquakes are located within the Cerdanya Basin (e.g. in 1876 and 1894, according to Baize et al., 2002 and references therein). Moreover, some authors (e.g. Briais et al., 1990; Baize et al., 2002) have proposed the Cerdanya fault as the possible seismogenic source of the seismic crisis of $1427-1428$ ( $\mathrm{I}_{\max }=$ VIII - XIX). Contrarily, Fleta et al. (2001) and Perea (2009) have identified the Amer Fault (Fig. 3) as the seismogenic source of the two earthquakes occurring in 1427, and Perea (2009) has suggested that the stress transfer produced at those earthquakes could have triggered the 1428 event, whose epicentre (as determined by Olivera et al., 2006) locates in a northernmore area. No systematic research on active faults has been performed within that area, i.e. between "Olot" and "Cerdanya" names in figure 3.

The activity of the Conflent Fault (structure 32 on Table 1 and 2; Fig. 3) during the Plio-Quaternary has been the focus of several researches. Calvet (1999) has documented normal to strike-slip faulting only until the Early Pliocene. Maurel et al. (2008) have relied in the exhumation history of the Canigó Massif derived from thermochronological data to discard any uplift related to the Conflent Fault after the Middle Miocene and Carozza and Delcaillau (2000) have assigned a sinistral strike-slip mouvement to the Conflent Fault during that period based on the analysis of the macrogeomorphology. Moreover, Carozza and Baize (2004) interpreted the faceted spurs of the fault as erosional-exhumed features, dating from the previous extensional period. Recent studies performed by Petit and Mouthereau (2011) on the slope development of the Conflent Scarp has suggested that the freshness of the faceted spurs is not the result of the fault activity but it is owed to the good preservation related to the fabric of the mylonitic rocks exposed.

The activity of the northern Têt Fault (structure 33 on Table 1 and 2; Fig. 3) has also been discussed. The multiproxy analysis of the fault scarp, the drainage network developed on the uplifted block (Querigut-Millas Massif) and the sedimentary infill of the adjacent Conflent Basin have led to Delcaillau et al. (2004) to conclude that the Conflent Basin was a pull-apart basin related to the sinistral-strike slip activity of the Conflent and northern Têt faults during the Pliocene. The authors have also stated that the northern Têt Fault does not seem active during and after the Pleistocene, with exception of its westernmost segment. Following a similar approach, Carozza and Baize (2004) have concluded that the geomorphologic expression of the northern Têt fault is mainly inherited from pre-Pliocene times. Calvet (1999) and Goula et al. (1999) have reported oblique reverse and sinistral strike-slip activity of this fault affecting Pliocene sediments, with up-to $1 \mathrm{~m}$ of vertical displacement in one of the two localities described, i.e. Ille-sur Têt and Nefiach.

North of this fault, tectonic deformation of recent deposits and landforms has been documented at three locations (Fig. 3): a) At Caramany (within the Agly Massif), several authors (Philip et al., 1992; Grellet et al., 1994; Calvet, 1999; Goula et al., 1999) have described the ca. $10 \mathrm{~m}$ thrusting (with sinistral component) of Paleozoic gneisses over Quaternary slope deposits along a N060 ${ }^{\circ} \mathrm{E}$ structure dipping to the SE. More recently, Baize et al. 
(2002) have considered that the neotectonic origin of this deformation is not clear in the field, and have suggested that the outcrop could also correspond to the deposition of slope deposits over an old fault plane. Calvet (1999) report two other outcrops in the same valley, all showing recent deposits affected by E-W reverse faults b) To the north of the Agly Massif, Ellenberger and Gottis (1967) refer to a fault zone oriented NE-SW, aligned with the Alaric-Cévennes Reliefs and made of several strands (L'Etagnol and la Peyrousse-Basse faults). The activity of these faults has caused the tilting of Quaternary glacis and the offset of Middle Quaternary travertines by $\sim 30 \mathrm{~m}$ along more than $0.5 \mathrm{~km}$. c) Within the Agly and the Millas crystalline Massifs, the activity of vertical faults offsetting glacial surfaces has been described by Lagasquie (1984) and Arthaud and Pistre (1993). We have not included any of these faults in the inventory of active faults due to the lack of a more detailed research clarifying the geometry and length of the structures observed.

The tectonic boundary between the Querigut and the Millas Massifs (Fig. 3) shows a cluster of seismicity down to $10 \mathrm{~km}$ (Souriau et al., 1998). The northernmost boundary of this zone is the NPF, which does not seem to have recent surface expression. To the north of the NPF, the Saint Paul de Fenouillet Epicentre (18/02/1996; Ml = 5.2) is located within the Agly Massif. This earthquake is the largest event since the installation of the improved seismic network in 1986 (Olivera et al., 1996), and occurred in the epicentral zone of another macroseismic event (23/7/1922). The earthquake caused to hydrogeological alterations (Toutain et al., 1999), and according to Sylvander et al. (2007), it took place several kilometres underneath the Agly Batholith, probably in an intracrustal fault parallel to the North Pyrenean Thrust Front (NPTF, Fig. 3).

\subsection{Induced Seismicity}

In the Aquitaine basin, more than 2000 clustered local low-moderated events $\left(M_{L}<4.2\right)$ were induced by the extraction of gas in the Lacq field since 1969 (Grasso and Feignier, 1990; Maury et al., 1992; Segall et al., 1994; Souriau and Pauchet, 1998; Bardainne et al., 2008). To the east of Iruña, a $4.6 \mathrm{mbLg}$ magnitude earthquake was widely felt on September 18 of 2004 in an area lacking significant seismic activity in recent times. The main shock was preceded by series of foreshocks reaching 3.3 mbLg magnitudes and was followed by an aftershock series of up to 200 events until the end of 2004, with a maximum mbLg magnitude of 3.8. This foreshock-aftershock series is largely interpreted as a rapid response case of reservoir-triggered seismicity, burst by the first impound of the Itoiz reservoir (Ruiz et al., 2006b; Jiménez et al., 2009; Durá-Gómez and Talwani, 2010; Santoyo et al., 2010; García-Mayordomo and Insua-Arévalo, 2011).

\section{Discussion}

The Pyrenees are a mountain region where the deformation rates are low and where the surface imprint of active faulting is easily obliterated by the enhanced Quaternary erosion, increasing human activity and extensive vegetation cover. It is then difficult to identify and characterize the active faults as illustrated by the limited number of conclusive studies dealing with active tectonics. Most of these studies focus on the areas where the maximum intensities of the great historical earthquakes took place (i.e, Lourdes, Arudy, Maladeta and Cerdanya-Olot zones, Fig. 3).

In spite of the sparse information, some models integrating seismological and/or neotectonic data have been proposed to characterize the Present-day stress field (e.g. Souriau and Pauchet, 1998; Goula et al., 1999; Calvet and Gunnell, 2008; De Vicente et al., 2008; Stich et al., 2010; Chevrot et al., 2011). In the present study, we reviewed for the first time, the different works performed on active faulting along the whole range. The time-window considered in such studies comprises hundred to thousands seismic cycles, which in the slow deforming areas usually overpass $10 \mathrm{ka}$, widely exceeding the seismological catalogs. Thus, even if more neotectonic studies are needed, the available neotectonic data provide valuable informations for the identification of the Present day stress state. In the following lines, we discuss the data reviewed above in the frame of a new model proposed to understand the neotectonics of the Pyrenees.

\subsection{High chain vs Low chain}

The active structures identified in the Pyrenees are reactivated faults inherited from the Variscan and Alpine orogenies or from the Neogene Mediterranean rifting. The data reviewed in section 3 led us to distinguish the distribution of the tectonic activity of the Pyrenees in two major zones: the "High Chain" and the "Low Chain".

The High Chain of the Pyrenees corresponds to the Western and Central LTSD and some neighboring areas in the Eastern and Western Pyrenees characterized by relatively high mean altitudes (over ca. $1500 \mathrm{~m}$, e.g. the Basque, Canigò, Millas or Agly massifs). In these areas, all the data reviewed only show normal faulting since the late Miocene, suggesting the existence of a dominant ver- 
tical stress. This stress is in agreement with the extensive focal mechanisms recently published by De Vicente et al. (2008), Sylvander et al. (2008) and Chevrot et al. (2011). Nevertheless, since these areas are also characterized by high reliefs and high altitudes, some of the faults might be controlled by local gravitational or glacial-rebound forces at a valley scale, factors that are not representative of the regional stress field.

We refer to the Low Chain as the areas of the Pyrenees characterized by a relatively low mean altitude (below ca. $1500 \mathrm{~m}$ ). These areas are located within the foreland basins and the piedmont of the Pyrenees (included in the NWPZ, the Western and the Eastern Pyrenees). Most faults in this domain have been reactivated during the neotectonic period as reverse or strike-slip faults, suggesting that the geodynamic arrangement is still compressive in this area. This deformation is compatible with the NE-SW to NW-SE orientation of the main stress inferred by different authors (e.g. Souriau and Pauchet, 1998; Goula et al., 1999; Baize et al., 2002). These studies are sparse and in many cases, the role of additional factors, as the salt tectonics or the glacial tectonics has not been clarified.

\subsection{Neotectonic model}

In the following lines, we propose a neotectonic model to explain the contrasting neotectonics of the High and the Low Chain by considering the most outstanding difference between them: the mean altitude. To analyze how can the altitude play a crucial role in the variation of the stresses across an "inactive" orogen, one should pay attention to the surface processes and the geomorphological evolution of these areas. In the last decades, several works (Vanara et al., 1997; Vanara, 2000; Perez-Vila et al., 2001; Agustí et al., 2006; Calvet and Gunnell, 2008; Gunnell et al., 2008; 2009; Lacan, 2008; Ortuño, 2008; Suc and Fauquette, 2012; Ortuño et al., accepted) have reported postorogenic surface uplift $>0.5 \mathrm{~km}$ and up to $2 \mathrm{~km}$ since the late Miocene at several sites, all located at the High Chain. The same occurs with the data on post-orogenic enhanced exhumation (Fitzgeral et al., 1999; Calvet and Gunnell, 2008; Maurel et al., 2008; Gunnell et al., 2008; 2009; Metcalf et al., 2009; Méresse, 2010), which can be owed to the surface uplift and/or enhanced erosion.

In the absence of sufficiently large orogenic forces that could explain the surface uplift as a consequence of orogenic building the most probable cause of the observed uplift is the presence of isostatic forces. The possible factors that have been discussed as the causes of the isostatic compensation of the chain are 1) the loss of weight due to erosion, suggested by Lacan (2008), Ortuño (2008) and
Ortuño et al. (accepted) for the Western and Central High chain, 2) the partial loss of the subducted lithosphere, proposed by Gunnell et al. (2008) and Gunnell et al. (2009) for the Eastern Pyrenees on the light of the tomographic study performed by Souriau et al. (2008) and 3) the combination of erosion and tectonic denudation relating the Neogene rifting process suggested by (Lewis et al., 2000) for NE Iberia. As pointed by the authors, buoyancy forces related to lateral differences in the mantle density probably reinforced this phenomenon. Options $\mathrm{b}$ and $\mathrm{c}$ do not apply for the Central and Western Pyrenees, although they might explain part of the activity of the normal faults located in the Eastern Pyrenees and next to areas of enhanced post-orogenic exhumation (e.g. vertical faults in the Querigut, Millas and Canigó massifs). For the rest of the High Chain, the isostatic response to relatively higher erosion seems to be the simplest explanation for the uplift documented.

In addition to the topographic gradient leading to the river entrenchment, other physical factors as the effects of successive glaciations, the weathering characterising peri-glacial environments (e.g. the effect of frost wedging) and the local absence of vegetation cover have accentuated the erosion in the High Chain with respect to the Low chain of the Pyrenees. This contrast in the erosion rate is probably resulting on differential uplift by isostatic compensation (Lacan, 2008; Ortuño, 2008; Ortuño et al., accepted).

Hivert (2011) and Hivert et al. (2011) have recently modelled the effects of the erosion on the distribution of the deformation at the Pyrenean range. The authors assume an isostatically compensated crustal root and test the model using different erosion laws and convergence rates. They conclude that depending on the erosion rate, extension can be observed within the inner part of a range even for convergence rates of several $\mathrm{mm} / \mathrm{yr}$. The linkage of local erosion and isostatic uplift has been the subject of thorough researches explaining the Present-day differences in uplift rates through particular cross sections of the Alps (e.g. Schlunegger and Hinderer, 2001; Champagnac et al., 2007). In our opinion, the model of Hivert (2011) and Hivert et al. (2011) can apply for the Central and Western parts of the chain, and should be tested in future researches by incorporating the location of the known active faults and well constrained variations in the erosion rate.

\section{The Eastern Pyrenees: a complex history}

At the Eastern Pyrenees, the recent geodynamical evolution has apparently been more complex than in the rest of the chain. The present-day macromorphology of this 

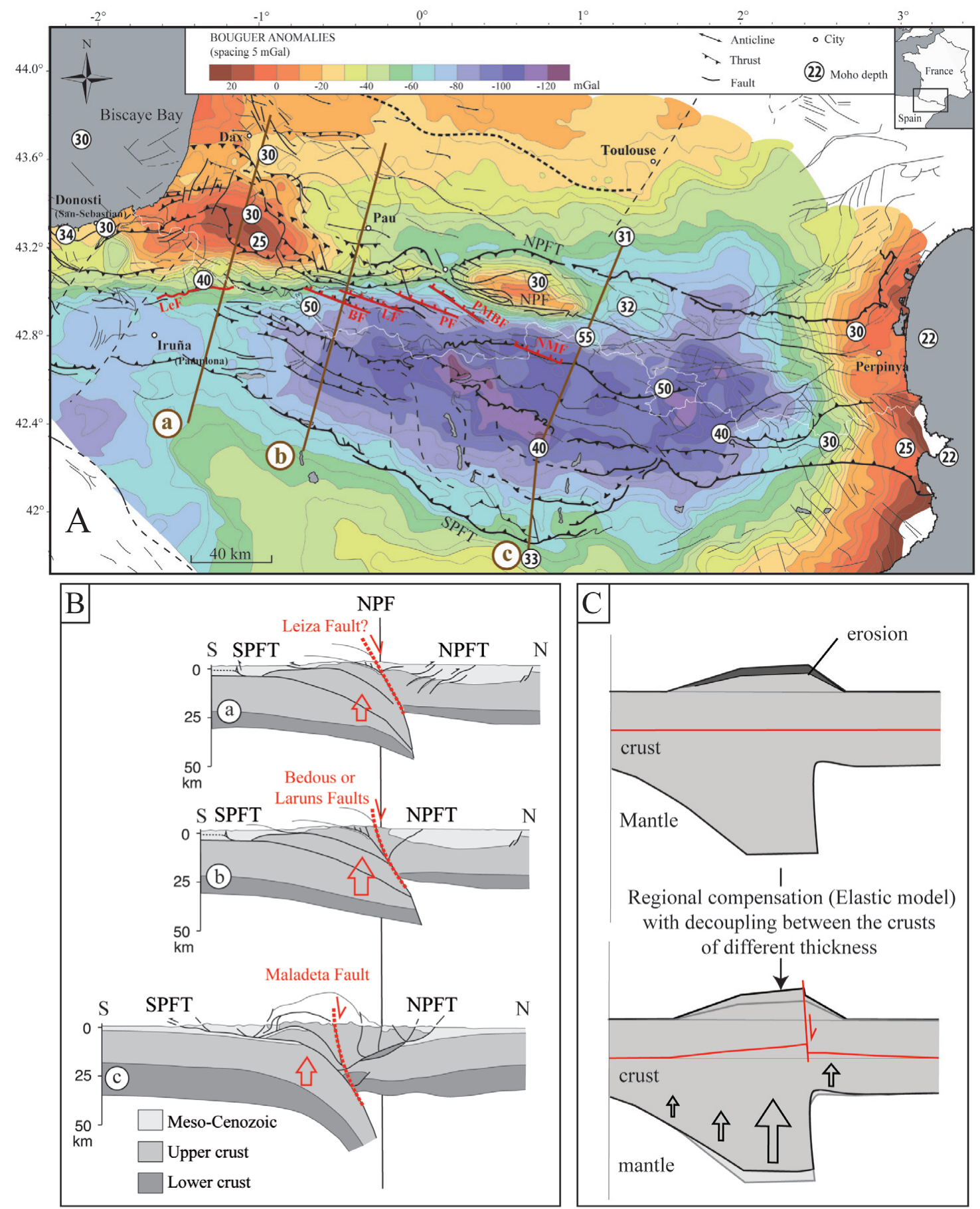

Fig. 4.- A: Main normal faults at the interface between the crusts of different thickness ploted on the Bouger anomaly map (modified from Bayer et al., 1996 and Casas-Sainz et al., 1997); the Moho depth is also represented (modified from Vergès et al., 1995); B: Structural cross sections of the chain showing the main normal faults distinguished on A and their relation with the change in crustal thickness: a) the westernmost Pyrenees (modified from Daignières et al., 1994); b) the Central-Western Pyrenees (modified from Séguret and Daignières, 1986; Casas-Sainz and Pardo, 2004), c) The Central Pyrenees (Ecors profile: Muñoz, 1992); C: Shematic model of isostatic compensation of the erosion in case of decoupled crusts (modified from Lacan, 2008). Acronyms: LeF, Leiza Fault; BF, Bedous Fault; LF, Laruns Fault; PF, Pierrefitte Fault; PMBF, Pic du Midi du Bigorre Fault; NMF, North Maladeta Fault; NPFT, North Pyrenean Frontal Thrust; NPF, North Pyrenean Fault; SPTF; South Pyrenean Frontal Thrust.

Fig. 4.- A: Fallas normales principales en la interfacie entre cortezas de diferente espesor proyectadas en el mapa de anomalías de Bouguer (modificado de Bayer et al., 1996 and Casas-Sainz et al., 1997); se ha incluido la profundidad de la Moho (modificada de Vergès et al., 1995); B: Secciones estructurales de la cadena mostrando las fallas normales principales diferenciadas en A y su relación con los cambios de espesor cortical: a) Pirineos Orientales (modificado de Daignières et al., 1994); b) Pirineos Centrales-Orientales (modificado de Séguret and Daignières, 1986; Casas-Sainz and Pardo, 2004), c) Pirineos Centrales (perfil Ecors: Muñoz, 1992); C: Modelo esquemático de la compensación isostática en respuesta a la erosión en caso de cortezas desacopladas (modificado de Lacan, 2008). Acrónimos: LeF, Falla de Leiza; BF, Falla de Bedous; LF, Falla de Laruns; PF, Falla de Pierrefitte; PMBF, Falla de Pic du Midi du Bigorre; NMF, Falla Norte de la Maladeta; NPFT, Cabalgamiento Frontal Norpirenaico; NPF, Falla Norpirenaica; SPTF; Cabalgamiento Frontal Surpirenaico. 
area seems to mainly reflect the Neogene Mediterranean extensive episode (Baize et al., 2002). However, the neotectonic data reviewed in this paper seems to indicate that this episode, controlled by a mean NW-SE extension (e.g. Roca and Guimera, 1992) was followed by a compressional stress regime with a horizontal NE-SW to NW-SE orientation, as suggested by Philip et al. (1992), Grellet et al. (1994), Calvet (1999) and Goula et al. (1999) among others. Furthermore, the focal mechanisms obtained for earthquakes in this area are compatible with a N-S compression (Souriau and Pauchet, 1998; Goula et al., 1999).

The crustal thinning associated with the Neogene rifting seems to have acted jointly with the erosion of the "Thermal Pyreneen slab" proposed by Gunnell et al. (2008; 2009). This last event could be responsible from a rapid post-orogenic uplift of the Eastern Pyrenees reported by different authors (Pérez-Vila et al., 2001; Agustí et al., 2006; Suc and Fauquette, 2012) and possibly reflected in the exhumation history of the area (Calvet and Gunnell, 2008; Maurel et al., 2008).

During the Plio-Quaternary, the low compressive stress resulting from the African-Europeen convergence could have been enough to reactivate major inherited faults as it was proposed for the foreland and piedmont areas. Even if the convergence stresses are low, the activity of reverse and strike slip faults oriented prependicular and oblique to the convergence vector in the Eastern Pyrenees could be feasible due to the low thickness of the crust and the absence of a crustal root (and its related vertical stress). Additionally, some of the Eastern Pyrenean faults located in high elevation zones (as those at Querigut and Millas Massifs) could have been activated by differential isostatic uplift in response to variations of the erosion.

Thus, one could say that the crust of this region ceased to be under the influence of the "Pyrenean orogenic evolution" during the Neogene Mediterranean rifting, and that the recent reactivation of some of the extensional structures under a submeridian compression has "re-incorporated" them to the post-orogenic history of the belt.

\section{Enhanced neotectonic activity and major changes in crustal thickness}

The uplift observed at the High Chain must be reflected in the activity of the structures that enable its decoupling with respect to the Low chain. The zones of high contrast in thickness of the crust between the different parts of the Pyrenees (e.g. Daignières et al., 1981; Pous et al., 1995; Souriau and Granet 1995; Souriau et al., 2008; Fig. 4A) are proposed here as preferable zones accommodating the differential uplift observed through the chain. Indeed, these areas of contrasting crustal thickness have been previously identified by Gallart et al. (1985) and Souriau and Pauchet (1998) as areas of enhance seismicity. Lacan (2008) has noted that the Leiza normal Fault, studied by Ruiz et al. (2006a) in the Westernmost Pyrenees, is exactly located at the interface between crusts of different thickness (Fig. 4B-a). More to the East, in the Western Pyrenees, the crustal thickness decreases abruptly from $45-50 \mathrm{~km}$ in the High Chain to $25-30 \mathrm{~km}$ in the NWPZ (Souriau and Granet 1995; Fig. 4B-b). The location of the major normal faults identified in the area (Bedous, Laruns, Pierrefitte, Pic du Midi du Bigorre faults) corresponds exactly to the step in depth between the two crusts of different thickness. This peculiarity suggests that the faults could play as decoupling structures accommodating differential isostatic uplift in response to changes in erosion (Lacan, 2008; Fig. 4B-b and 4-C).

Compared to this area, the lower instrumental seismicity recorded in the Central Pyrenees, where the contrast in crustal thickness is about $15 \mathrm{~km}$ (ECORS, Gallart et al., 1985) could be explained by a stronger coupling of the European and Iberian crusts, which may induce more regional isostatic compensation. However, the interface between crusts of different thickness at this area well correspond to the North Maladeta Fault (Fig 4-B-c), which accommodates differences in exhumation, and probably also uplift, as discussed by Ortuño et al. (accepted). The decoupling related to the isostatic compensation of the erosion through these three transects (Fig. 4-B) would explain the neotectonic activity above the present-day main plate boundary (Fig. 4-C).

In spite of the differences that we exposed about the evolution of the Eastern Pyrenees, the exhumation history of the Canigò Massif (Fig. 3), related to the post-orogenic reactivation of the Têt Fault (Calvet and Gunnel, 2008) could also be explained by such a model.

\section{Final remarks}

The present-day neotectonic and paleoseismological studies in the Pyrenees are too scarce to properly characterize the neotectonics of the range. The present-day knowledge on active faulting in the Pyrenees lead us to differentiate the range into two major zones: the High Chain, where active faults are controlled by vertical maximum stresses, and the Low Chain, where horizontal maximum stresses of variable orientation seem to be dominant. This distribution of these dominant stresses is explained within a neotectonic model which relates the dominant vertical stress to larger isostatic rebound (resulting from either enhanced erosion and/or adjustments derived from the loss of the slab) and the dominant hori- 
zontal stress to the effect of the convergent forces on a relatively thinner crust (locally combined with the effect of salt tectonics).

The differential isostatic compensation to the erosion explains well the neotectonic differentiation between High and Low Chain of the Pyrenees. Moreover, is in agreement with (1) the neotectonics and geomorphological data previously exposed, (2) the location of enhanced seismicity at the boudary between crusts of different thickness, and (3) the numerical simulations performed by Hivert, 2011 and Hivert et al., 2011. However, this review highlights the variety of the competing forces that take part into the definition of the state of stress all along the range. Further research is needed to better characterize the active faults, the seismicity and the uplift of the chain, and thus to validate the consistency of this neotectonic model.

The distribution of the active faults identified so far in the Pyrenees evidences that the most detailed neotectonic studies are located around the epicenters of the historical destructive earthquakes. The low Present-day deformation rates are related to large recurrence periods between consecutive earthquakes produced in a given structure. This makes the epicentral distribution of the historical catalog little representative of the areas that might experience destructive events in the future. The absence of neotectonics studies in other areas poses a large handicap in the understanding of the geodynamical evolution of the chain and thus, in the improvement of the seismic hazard zonation of the chain. Under these circumstances, we highly recommend to further study the areas where neotectonic activity has been reported, and to conduct neotectonic researches at those areas of the Pyrenees characterized by structural and orographical features comparable to those areas where active tectonics has been shown.

\section{Acknowledgements}

We are indebted to Bertrand Nivière and Pere Santanach, who advised our $\mathrm{PhD}$ thesis and provided us with helpful and inspiring discussions on the subject of this paper. The RSSP and the IGN seismological services are thanked for providing seismic data from their permanent stations. We thank Xavier Goula and an anonymous referee for their reviews and their pertinent comments that helped us to improve significantly the manuscript.

\section{References}

Agustí, J., Oms, O., Furió, M., Pérez-Vila, M.J., Roca, E. (2006): The Messinian terrestrial record in the Pyrenees: The case of Can Vilella (Cerdanya Basin). Palaeogeogr. Palaeoclimatol. Palaeoecol. 238,
179-189. doi:10.1016/j.palaeo.2006.03.024.

Alasset, P.J. (2005): Sismotectonique et identification des sources sismiques en domaine à déformation lente: cas des Pyrénées Occidentales et des Alpes du Nord (France). Le tsunami créé par le séisme de Zemmouri (Mw=6.9, Algérie) du 21 Mai 2003. PhD thesis, Université de Strasbourg I : $214 \mathrm{p}$.

Alasset, P., Meghraoui, M. (2005): Active faulting in the western Pyrenees (France): Paleoseismic evidence for late Holocene ruptures. Tectonophysics 409, 39-54. doi:10.1016/j.tecto.2005.08.019.

Arthaud, F., Pistre, S. (1993): Les fractures et les paléocontraintes du granite hercynien de Millas (zone axiales des Pyrénées): un cas d'etude de la tectonique cassante d'un aquifère de socle. Geodin. Acta 6(3), 187-201.

Asensio, A., Khazaradze, G., Echeverria, A., King, R.W., Vilajosana, I. (2012): GPS studies of active deformation in the Pyrenees. Geophys. J. Int. doi: 10.1111/j.1365-246X.2012.05525.x.

Autran, A., Blès, J.L., Combes, Ph., Cushing, M., Dominique, P., Durouchoux, Ch., Mohammadioun, B., Terrier, M. (1998): Probabilistic seismic hazard assessment in France - Part 1 : Seismotectonic zonation. ECEE'98, Paris, France.

Baize, S., Cushing, M., Lemeille, F., Granier, T., Grellet, B., Carbon, D., Combes, P., Hibsch, C. (2002): Inventaire des indices de rupture affectant le Quaternaire, en relation avec les grandes structures connues en France métropolitaine et dans les régions limitrophes. Mémoire hors série, Soc. Géol.Fr., 175, 142 p.

Bardainne, T., Dubos-Sallée, N., Sénéchal, G., Gaillot, P., Perroud, H. (2008): Analysis of the induced seismicity of the Lacq gas field (Southwestern France) and model of deformation. Geophysical Journal International 172, 1151-1162. doi:10.1111/j.1365246X.2007.03705.x

Barnolas, A., Chiron, J.-C. (1996): Synthèse Géologique et Géophysique des Pyrénées, Volume 1: Introduction. Géophysique. Cycle Hercynien, ed. BRGM-ITGE, Orléans, France: 729 p.

Baubron, J.C., Rigo, A., Toutain, J.P. (2002): Soil gas profiles as a tool to characterise active tectonic areas: the Jaut Pass example (Pyrenees, France). Earth Planet. Sci. Lett. 196, 69-81. doi: 10.1016/ S0012-821X(01)00596-9.

Bayer, B., De Cabissole, B., Casas, A., Corpel, J., Debeglia, N. (1996): Anomalie de Bouguer des Pyrénées, In: A. Barnolas, et J.C. Chiron (eds.), Synthèse Géologique et Géophysique des Pyrénées, BRGMITGE, Orléans, 1, 38-41.

Beaumont, C., Muñoz, J.A., Hamilton, J., Fullsack, P. (2000): Factors controlling the Alpine evolution of the central Pyrenees inferred from a comparison of observations and geodynamical models, $J$. Geophys. Res. 105, B4, 8121-8145. doi:10.1029/1999JB900390.

Billi, A., Faccenna, C., Bellier, O., Minelli, L., Neri, G., Piromallo, C., Presti, D., Scrocca, D., Serpelloni, E. (2011): Recent tectonic reorganization of the Nubia-Eurasia convergent boundary heading for the closure of the western Mediterranean. Bull. Soc. géol. France 182, 279-303. doi: 10.2113/gssgfbull.182.4.279

Bordonau, J., Vilaplana, J.M. (1986): Géomorphologie et tectonique récente dans le Val d'Aran (Zone Axiale des Pyrénées Centrales, Espagne). Rev. Géol. Dyn. Géogr. Phys., 27, p. 303-310.

Briais, A., Armijo, R., Winter, T., Tapponnier, P., Herbecq, A. (1990): Morphological evidence for Quaternary normal faulting and seismic hazard in the Eastern Pyrenees. Annales Tectonicae 4(1), 19-42.

Cabrera, L., Roca, E., Santanach, P. (1988): Basin formation at the end of a strike-slip fault: the Cerdanya Basin (eastern Pyrenees). Jour. Geol. Soc. London 145, 261-268. doi:10.1144/gsjgs.145.2.0261.

Calvet, M. (1985): Néotectonique et mise en place des reliefs dans l'Est des Pyrénées; l'exemple du horst des Albère. Rev. Géol. Dyn. Géogr. Phys. 26, 119-130.

Calvet, M. (1996): Morphogenèse d'une montagne méditerranéenne, 
les Pyrénées orientales. Documents du BRGM 255, 1170.

Calvet, M. (1999): Régimes des contraintes et volumes de relief dans l'est des Pyrénées. Géomorphologie: relief, processus, environnement 3, 253-278.

Calvet, M., Gunnell, Y. (2008): Planar landforms as markers of denudation chronology: An inversion of East Pyrenean tectonics based on landscape and sedimentary basin analysis. Geological Society Special Publication 296, 147-166. doi: 10.1144/SP296.10

Carbon, D., Combes, Ph., Cushing, M., Granier, Th., Grellet, B. (1995): Rupture de surface postpléistocène moyen dans le bassin aquitain. C. R. Acad. Sci. Paris, 320, 311-317

Carozza, J-M. (1998): Evolution des systèmes géomorphologiques en contexte orogénique: l'exemple des bassins d'alimentation du Rosselló. Approche morphotectonique. $\mathrm{PhD}$ Thesis, Université de Toulouse 2: $398 \mathrm{p}$.

Carozza, J.M., Delcaillau, B. (2000): Réponse des bassins versants à l'activité tectonique: l'exemple de la terminaison orientale de la chaîne pyrénéenne. Approche morphotectonique. Géomorphologie 1, 45-60.

Carozza, J.M., Baize, S.M. (2004): L'escarpement de faille de la Têt est-il le résultat de la tectonique active Plio-Pléistocène ou d'une exhumation Pléistocène ? Comptes Rendus Geosciences 336, $217-$ 226. doi: 10.1016/j.crte.2003.10.026

Casas-Sainz, A., Kearey, P., Rivero, L., Adam, C. (1997): Gravity anomaly map of the Pyrenean region and a comparison of the deep geological structure of the western and the eastern Pyrenees, Earth Planet. Sc. Lett. 150, 65-78. doi:10.1016/S0012-821X(97)00087-3.

Casas-Sainz, A., Pardo, G. (2004): Estructura pirenaica y evolución de las cuencas sedimentarias en la transversal Huesca-Oloron, Geo-guías 1 : itinerarios geológicos por Aragón, p. 63-96.

Champagnac, J., Molnar, P., Anderson, R., Sue, C., Delacou, B. (2007): Quaternary erosion-induced isostatic rebound in the western Alps. Geology 35, 195-198. doi:10.1130/G23053A.1

Chevrot, S., Sylvander, M., Delouis, B. (2011): A preliminary catalog of moment tensors for the Pyrenees, Tectonophysics 510, 239-251. doi: 10.1016/j.tecto.2011.07.011.

Choukroune, P., ECORS Pyrenees Team (1989): The Ecors Pyrenean deep seismic profile reflection data and the overall structure of an orogenic belt. Tectonics 8, 23-39. doi:10.1029/TC008i001p00041.

Courjault-Radé, P., Darrozes, J., Gaillot, P. (2009): The M=5.1 1980 Arudy earthquake sequence (western Pyrenees, France): a revisited multi-scale integrated seismologic, geomorphologic and tectonic investigation. Int. J. Earth Sci. doi: 10.1007/s00531-008-0320-5.

Daignières, M., Gallart, J., Banda, E. (1981): Lateral variation of the crust in the North PyreneanZone, Ann. Géophys. 37, 435-456.

Daignières, M., Séguret, M., Specht, M., ECORS team (1994): The Arzacq-western Pyrenees ECORS deep seismic profile, Publ. Eur. Assoc. Pet. Geol. 4, 199-208.

Darrozes, J., Gaillot, P., Courjault-Radé, P. (1998): 2D propogation of a sequence of aftershocks combining an isotropic wavelet transform and gis. Physics and Chemistry of The Earth, 23, 303-308, doi: 10.1016/S0079-1946(98)00029-9.

Delcaillau, B., Carozza, J.M., Font, M. (2004): Le segment nord de la faille de la Têt (Pyrénées-Orientales): fonctionnement néogène et implications géomorphologiques. Bull. Soc. géol. France 175, $257-$ 272. doi: $10.2113 / 175.3 .257$.

Delfaud, J., Pailhé, P., Thomas, G. (1985): Etude cartographique de la dynamique du piémont pyrénéen à propos du levé de la carte de Morlaas, apport des méthodes géologiques et géomorphologiques. In: F. Pau (ed.), CERCG du CNRS, p. 355-369.

Delouis, B., Haessler, H., Cisternas, A., Rivera, L. (1993): Stress tensor determination in France and neighbouring regions. Tectonophysics 221, 413-437.
DeMets, Ch., Gordon, R.G., Argus, D.F., Stein, S. (1994): Effect of recent revisions to the geomagnetic reversal time scale on estimate of current late motions. Geophys. Res. Lett. 21, 2191-2194. doi:10.1029/94GL02118.

De Vicente, G., Cloetingh, S., Muñoz-Martín, A., Olaiz, A., Stich, D., Vegas, R., Galindo-Zaldívar, J., Fernández-Lozano, J. (2008): Inversion of moment tensor focal mechanisms for active stresses around the microcontinent Iberia: Tectonic implications., Tectonics 27, TC1009, doi: 10.1029/2006TC002093.

Dominique, P., Autran, A., Blès, J.L., Fitzenz, D., Samarcq, F., Terrie, M., Cushing, M., Gariel, J.C., Mohammadioun, B., Combes, Ph., Durouchoux, Ch., Goula, X. (1998): Probabilistic seismic hazard assessment in France - Part 2 : Probabilistic approach : Seismic hazard map on the national territory (France). ECEE'98, Paris, France.

Dubos, N. (2003): Contribution à l'évaluation du risque sismique dans les Pyrénées centrales. PhD. Thesis, Université Toulouse III: 205 p.

Dubos, N., Sylvander, M., Souriau, A., Ponsolles, C., Chevrot, S., Fels, J., Benahmed, S. (2004): Analysis of the 2002 May earthquake sequence in the central Pyrenees, consequences for the evaluation of the seismic risk at Lourdes, France. Geophys. J. Int. 156, 527 540. doi: 10.1111/j.1365-246X.2004.02091.x.

Dubos-Sallée, N., Nivière, B., Lacan, P., Hervouët, Y. (2007): A structural model for the seismicity of the Arudy (1980) epicentral area (Western Pyrenees, France). Geophys. J. Int. 171, 259-270, doi: 10.1111/j.1365-246X.2007.03499.x.

Durá-Gómez, I., Talwani, P. (2010): Reservoir-induced seismicity associated with the Itoiz Reservoir, Spain: a case study. Geophys. $J$. Int. 181, 343-356. doi:10.1111/j.1365-246X.2009.04462.x.

Ellenberger, F., Gottis, M. (1967): Sur les jeux de failles pliocènes et quaternaires dans l'arrière-pays narbonnais. Rev. Géogr. Phys. et de Géol. Dyn. 2, 153-159.

Fidalgo González, L. (2001): La cinématique de l'Atlantique Nord : la question de la déformation intraplaque, $\mathrm{PhD}$. Thesis, Université de Bretagne Occidentale: 293 p.

Fitzgerald, P.G., Muñoz, J.A., Coney, P.J., Baldwin, S.L. (1999): Asymmetric exhumation across the Pyrenean orogen: implications for the tectonic evolution of a collisional orogen. Earth and Planetary Science Letters 173, 157-170. doi:10.1016/S0012821X(99)00225-3.

Fleta, J.; Grellet, B.; Philip, H.; Escuer, J.; Goula, X., Bousquet, J.C. (1996): Les deformacions tectòniques en els materials plioquaternaris de la depressió de Tortellà-Besalú. Geologia de la conca lacustre de Banyoles-Besalú, Quaderns 17, 99-112.

Fleta, J., Goula, X. (1998): Paleosis Region IV: Eastern Pyrenees. Internet, http://www.astro.oma.be/PALEOSIS/.

Fleta, J., Santanach, P., Goula, X., Martinez, P., Grellet, B., Masana, E. (2001): Preliminary geologic, geomorphologic and geophysical studies for the paleoseismological analysis of the Amer fault (NE Spain). Netherlands Journal of Geosciences/ Geologie en Mijnbouw 80 (3-4), 243-253.

Gagnepain-Beyneix, J., Haessler, H., Modiano, T. (1982): The Pyrenean earthquake of February 29, 1980: an example of complex faulting, Tectonophysics 85, 273-290. doi:10.1016/00401951(82)90106-8.

Gaillot, P., Darrozes, J., Courjault-Radé, P., Amorese, D. (2002): Structural analysis of hypocentral distribution of an earthquake sequence using anisotropic wavelets: Method and application, J. Geophys. Res. 107, B10, 2218, doi: 10.1029/2001JB000212.

Gallart, J., Olivera, C., Daignières, M., Hirn, A. (1982): Quelques données récentes sur la rélation entre fracture crustales et séismes dans les Pyrénées Orientales. Bull. Soc. Géol. France 24 (2), 293-98. 
Gallart, J., Daignères, M., Gagnepain-Beyneix J., Hirn, A. (1985): Relationship between deep structure and seismicity in the western Pyrenees. Ann. Geophys. 3, 239-248.

Gallart, J., Díaz, J., Nercessian, A., Mauffret, A., Dos Reis, T. (2001): The eastern end of the Pyrenees: seismic features at the transition to the NW Mediterranean. Geophys. Res. Lett. 28, 2277-2280. doi: 10.1029/2000GL012581.

García-Mayordomo, J., Insua-Arévalo, J.M. (2011): Seismic hazard assessment for the Itoiz dam site (Western Pyrenees, Spain), Soil. Dyn. Earthq. Eng. 31, 1051-1063. doi: 10.1016/j.soildyn.2011.03.011.

Goula, X., Olivera, C., Fleta, J., Grellet, B., Lindo, R., Rivera, L., Cisternas, A., Carbon, D. (1999): Present and recent stress regime in the eastern part of the Pyrenees. Tectonophysics 308, 487-502. doi: 10.1016/S0040-1951(99)00120-1.

Grasso, J., Feignier, B. (1990): Seismicity induced by gas production: II. Lithology correlated events, induced stresses and deformation. Pure appl. Geophys. 134, 427-450.

Grellet, B., Phillip, H., Bousquet, J.C., Fleta, J., Escuer, J., Goula, X., Granier, Th. (1994): Inversion de regime tectonique dans les Pyrenees Orientales depuis le Pliocene. Actes du Colloque GEOPROSPECTIVE Paris, UNESCO, 289-298.

Gunnell Y., Zeyen H., Calvet M. (2008): Geophysical evidence of a missing lithospheric root beneath the Eastern Pyrenees: consequences for post-orogenic uplift and associated geomorphic signatures. Earth and Planetary Science Letters 276, 302-313. doi: 10.1016/j.eps1.2008.09.031.

Gunnell Y., Calvet M., Brichau S., Carter A., Aguilar J.P., Zeyen H. (2009): Low long-term erosion rates in high-energy mountain belts: insights from thermo- and biochronology in the Eastern Pyrenees. Earth and Planetary Science Letters 278, 208-218. doi: 10.1016/j. eps1.2008.12.004.

Gutiérrez, F., Ortuño, M., Lucha, P., Guerrero, J., Acosta, E. Coratza, P., Piacentini, D., Soldati M., Beguería, S. (2008): Late Quaternary episodic displacement on a sackung scarp in the central Spanish Pyrenees. Secondary paleoseismic evidence? Geodinamica Acta, 21(4), 187-202. doi: 10.3166/ga.21.187-202.

Herraiz, M., De Vicente, G., Lindo-Ñaupari, R., Giner, J., Simón, J.I., González-Casado, J.M., Vadillo, O., Rodríguez-Pascua, M.A., Cicuéndez, J.I., Casas, A., Cabañas, L., Rincón, P., Cortés, A.L., Ramírez, M., Lucini, M. (2000): The recent (upper Miocene to Quaternary) and present tectonic stress distributions in the Iberian Peninsula. Tectonics 19, 762-786. doi: 10.1029/2000TC900006.

Hervouët, Y. (1997): Déformations alpines, inversion tectonique négative et karstogenèse : exemple de la Pierre Saint-Martin (Pyrénées-Atlantiques, France). Bull. Soc. géol. France 168, 663-674.

Hivert, F. (2011): Modélisation numérique de l'érosion et de l'extension dans les chaînes de montagnes peu actives : application au cas des Pyrénées. MsC. Thesis, Université Montpellier 2.

Hivert, F., Vernant, P., Chery, J., Cattin, R., Rigo A. (2011): Can the gravitational collapse paradigm withstand the geodetic and seismologic observations in the Alps and the Pyrenees, birth of a new paradigm?, American Geophysical Union, Fall Meeting 2011, abstract EP41D-0636.

Insua-Arévalo, J.M.,García-Mayordomo, J. (2009): Upper Pleistocene tectonic activity in the Central Pyrenees range (Navarra, N Spain). In : R. Pérez-López et al. (ed.), Book of abstracts of the 1st INQUAIGCP-567 International Workshop on Earthquake Archaeology and Paleoseismology, Baelo Claudia, Spain : 60-62.

Jiménez, M.J., García-Fernández, M., GSHAP Ibero-Maghreb Working Group (1999): Seismic hazard assessment in the Ibero-Maghreb region. Annali di Geofisica, 42(6), 1057-1066. doi:10.4401/ag3774 .
Jiménez, A., Tiampo, K.F., Posadas, A.M., Luzón F., Donner, R. (2009): Analysis of complex networks associated to seismic clusters near the Itoiz reservoir dam. The European Physical JournalSpecial Topics 174, 181-195. doi:10.1140/epjst/e2009-01099-1.

Klarica, S., Hervouët, Y., Bauer, J. (2001): Karst et extensions gravitaires d'altitude: le massif du Jaout (Pyrénées occidentales, France). Geologica Belgica 4(3-4), 213-229.

Lacan, P. (2008): Activité Sismotectonique Plio-Quaternaire de l'Ouest des Pyrénées. PhD. Thesis. Université de Pau et des Pays de l'Adour: $284 \mathrm{p}$.

Lacan, P., Nivière, B., Rousset, D., Sénéchal, P. (2012): Late Pleistocene folding above the Mail Arrouy Thrust, North-Western Pyrenees (France). Tectonophysics 541-543, 57-68. doi: 10.1016/j. tecto.2012.03.022.

Lagasquie, J.J. (1984): Géomorphologie des granites : les massifs granitiques de la moitié orientale des Pyrénées françaises. Paris: éditions du Centre national de la recherche scientifique, $374 \mathrm{p}$.

Lambert, J., Levret-Albaret, A., Cushing, M., Durouchoux, C. (1996): Mille ans de séismes en France. Ouest Editions (ed.), Nantes, France : $78 \mathrm{p}$.

Larrasoaña, J.C., Ortuño, Birks, H., M., Valero-Garcés, B., Parés, J.M., Copons, R., Camarero, L., Bordonau, J. (2010): Paleoenvironmental and palaeoseismic implications of a 3700-year sedimentary record from proglacial Lake Barrancs (Maladeta Massif, Central Pyrenees, Spain). Paleogeography, Paleoclimatology, Paleoecology 294, 83 -93. doi:10.1016/j.palaeo.2009.04.003.

Lewis, C. J., Vergés, J., Marzo, M. (2000): High mountains in a zone of extended crust: Insights into the Neogene-Quaternary topographic development of northeastern Iberia, Tectonics 19, 86-102.

MacKenzie, D. (1972): Active tectonics of the Mediterranean region, G. J. R. Soc. 30, 109-185.

Marin, S., Avouac, J.-P., Nicolas, M., Schlupp, A. (2004): A probabilistic Approach to Seismic Hazard in Metropolitan France. Bull. Seism. Soc. Am. 94, 2137-2163. doi: 10.1785/0120030232.

Mauffret A., Durand de Grossouvre B., Dos Reis A.T., Gorini C., Nercessian A. (2001): Structural geometry in the eastern Pyrenees and western Gulf of Lion (Western Mediterranean). Journal of Structural Geology 23, 1701-1726. doi: 10.1016/S0191-8141(01)00025-6.

Maurel, O., Moniè, P., Pik, R., Arnaud, N., Brunel, M., Jolivet, M. (2008): The Meso-Cenozoic thermo-tectonic evolution of the eastern Pyrenees; an (super 40) Ar/ (super 39) Ar fission track and (UTh)/He thermochronological study of the Canigò and Mont-Louis Massifs. International Journal of Earth Sciences 97, 565-584. doi: 10.1007/s00531-007-0179-x.

Maury, V., Grassob, J.-R., Wittlinger, G. (1992): Monitoring of subsidence and induced seismicity in the Lacq gas field (France): the consequences on gas production and field operation. Engineering Geology 32, 123-135. doi: 10.1016/0013-7952(92)90041-V.

Meigs, A.J., Burbank, D.W. (1997): Growth of the South Pyrenean orogenic wedge. Tectonics 16, 239-258.

Méresse, F. (2010): Dynamique d'un prisme orogénique intracontinental: évolution thermochronologique (traces de fission sur apatite) et tectonique de la Zone Axiale et des piémonts des Pyrénées centro-occidentales. PhD. Thesis, Université de Montpellier 2: $213 \mathrm{p}$.

Metcalf, J.R., Fitzgerald, P.G., Baldwin, S.L., Muñoz, J.A. (2009): Thermochronology of a convergent orogen: Constraints on the timing of thrust faulting and subsequent exhumation of the Maladeta Pluton in the Central Pyrenean Axial Zone. Earth and Planetary Science Letters 287, 488-50. doi: 10.1016/j.epsl.2009.08.036.

Muñoz, J.A. (1992): Evolution of a continental collision belt: ECORSPyrenees crustal balanced cross-section. In: MCCLAY, K.R. (ed.), Thrust Tectonics, Chapman and Hall, London: 235-246. 
Muñoz, J.A. (2002): Alpine tectonics I: the Alpine system north of the Betic Cordillera. Tectonic setting; The Pyrenees. In: W. Gibbons, T. Moreno (eds.), Geology of Spain, Geol. Soc (London): 370-385. Neopal (2012): http://www.neopal.net/donnees indices.asp?DPT=66. Nicolas, M., Santoire, J., Delpech, P. (1990): Intraplate seismicity: new seismotectonic data in western Europe, Tectonophysics 179, 27-53. doi: 10.1016/0040-1951(90)90354-B.

Nivière, B., Lacan, P., Regard, V., Delmas, M., Calvet, M. (submitted): Cosmogenic dating of an alluvial terrace in the foothills of the western Pyrenees. Implication on the late glacial chronology, Submitted to Geomorphology.

Nocquet, J., Calais, E. (2004): Geodetic measurements of crustal deformation in the western Mediterranean and Europe. Pure Appl. Geophys., 161, 661-681. doi: 10.1007/s00024-003-2468-z.

Olivera, C., Gallart, J., Goula, X., Banda, E. (1986): Recent activity and seismotectonics of the Eastern Pyrenees. Tectonophysics 129, 367-380. doi:10.1016/0040-1951(86)90262-3.

Olivera, C., Riera, A., Lambert, J., Banda, E., Alexandre, P. (1994): Els terratrèmols de l'any 1373 al Pirineu. Efectes a Espanya $i$ França. Servei Geológic de Catalunya: 220 p.

Olivera, C., Fleta, J. (1996): Analysis of Microearthquakes (19861993 ) in Vielha Area, Axial Zone of the Central Pyrenees. European Seismological Commision, XXV General Assembley, Reykjavik, Iceland: 288-293.

Olivera, C., Redondo, E., Lambert, J., Riera Melis, A., Roca, A. (2006): Els terratrèmols dels segles XIV i XV a Catalunya. Institut Cartogràfic de Catalunya, Monografies 30, 407p.

Olaiz, A.J., Muñoz-Martín, A., De Vicente, G., Vegas, R., Cloetingh, S. (2009): European continuous active tectonic strain-stress map. Tectonophysics 474, 33-40. doi: 10.1016/j.tecto.2008.06.023.

Ortuño, M. (2008): Deformación activa en el Pirineo Central: la falla Norte de la Maladeta y otras fallas activas. $\mathrm{PhD}$. Thesis, Universitat de Barcelona: $346 \mathrm{p}$.

Ortuño, M., Queralt, P., Martì, A., Ledo, J., Masana, E., Perea, H., Santanach, P. (2008): The North Maladeta Fault (Spanish Central Pyrenees) as the Vielha 1923 earthquake seismic source: Recent activity revealed by geomorphological and geophysical research, Tectonophysics 453, 246-262, doi: 10.1016/j.tecto.2007.06.016.

Ortuño, M. (2009): Criteria to distinguish neotectonic with from other active faults: exemples from the Central Pyrenees. Abstract volume of the 1st INQUA-IGCP -567 International Workshop on Earthquake Archaeology and Palaeoseismology, 98-101.

Ortuño, M., Martí, A., Martín-Closes, C., Jiménez-Moreno, G., Martinetto, E., Santanach, P. (accepted): Palaeoenvironments of the Upper Miocene Prüedo basin: implications for the uplift of the Central Pyrenees. Journal of the Geological Society of London.

Pailhé, P., Thomas, G. (1984): Approche de la néotectonique des confins basco-béarnais, Xème R.A.S.T., p. 426.

Paquet, J., Mansy, J.L. (1992): Evolution alpine du massif nord-pyrénéen de l'Agly (Pyrénées-Orientales) = Alpine evolution of the North-Pyrenean Agly massif (Eastern Pyrenees). C. R. Acad. Sci. Paris 2, 315, 4, 487-494.

Pauchet, H., Rigo, A., Rivera, L., Souriau, A. (1999): A detailed analysis of the February 1996 aftershock sequence in the eastern Pyrenees, France, Geophys. J. Int. 137, 107-127. doi: 10.1046/j.1365246x.1999.00776.x.

Petit, C., Mouthereau, F. (2011): The Têt fault escarpment in Eastern Pyrenees: how anisotropic diffusive transport may preserve steep slopes imitating active fault scarps.EGU General Assembly. Geophysical Research Abstracts 13, EGU2011-2182.

Perea, H. (2009): The catalan seismic crisis (1427 and 1428): Geological sources and earthquake triggering. Journal of Geodynamics 47, 259-270. doi: 10.1016/j.jog.2009.01.002.
Perea, H., Masana, E., Santanach, P. (2012). The northwestern margin of the València trough, an active zone characterized by slow normal faults. A review. Journal of Iberian Geology 38, 33-56, doi: 10.5209/rev JIGE.2012.v38.n1.39204.

Pérez-Vila, M.J., Fauquette, S., Suc, J.P., Bessedik, M. (2001): Palynological contribution to estimation of Mio-Pliocene altitude of eastern Pyrenees. In: Agustí J, OMs O (eds.), Late Miocene to early Pliocene environments and ecosystems. Abstracts of the 2nd EEDEN Plenary Workshop Sabadell (Spain): 52-54.

Philip, H., Bousquet, J.C., Escuer, J., Fleta, J., Goula, X., Grellet, B. (1992): Présence de failles inverses d'âge quaternaire dans l'Est des Pyrénées: implications sismotectoniques. C. R. Acad. Sci. Paris 314, 1239-1245.

Pous, J., Julià, R., Solé Sugrañes, L. (1986): Cerdanya basin geometry and its implications on the neogene evolution of the Pyrenees. Tectonophysics 129, 355-365. doi: 10.1016/0040-1951(86)90261-1.

Pous, J., Ledo, J., Marcuello, A., Daignières, M. (1995): Electrical resistivity model of the crust and the upper mantle from a magnetotelluric survey through the central Pyrenees. Geophys. J. Int., 121, 750-762. doi: 10.1111/j.1365-246X.1995.tb06436.x.

Rebaï, S., Philip, H., Taboada, A. (1992): Modern tectonic stress field in the mediterranean region: evidence for variation in stress directions at different scales. Geophys. J. Int., 110, 106-140. doi: 10.1111/j.1365-246X.1992.tb00717.x.

Rigo A., Pauchet, H. Souriau, A. Grésillaud, A. Nicolas, M. Olivera, C. Figueras,S. (1997): The February 1996 earthquake sequence in the eastern Pyrenees: first results. J. Seismology 1, 3-14.

Rigo, A., Souriau, A., Dubos, N., Sylvander, M., Ponsolles, C. (2005): Analysis of the seismicity in the central part of the Pyrenees (France), and tectonic implications. J. Seismol. 9, 211-222, doi: 10.1007/s10950-005-2775-1.

Ruiz, M., Gallart, J., Díaz, J., Olivera, C., Pedreira, D., López, C., González-Cortina, J., Pulgar, J. (2006a): Seismic activity at the western Pyrenean edge. Tectonophysics 412, 217-235. doi: 10.1016/j.tecto.2005.10.034.

Ruiz, M., Díaz, J., Gallart, J., Pulgar, J., González-Cortina, J., López, C. (2006b): Seismotectonic constraints at the western edge of the Pyrenees: aftershock series monitoring of the 2002 February 21, 4.1 Lg earthquake. Geophys. J. Int. 166, 238-252. doi: 10.1016/j. tecto.2006.03.037.

Roca, E. (1996): La evolución geodinámica de la Cuenca CatalanoBalear y áreas adyacentes desde el Mesozoico hasta la actualidad. Acta Geol. Hispanica 29, 3-26.

Roca, E., Guimera, J. (1992): The neogene structure of the eastern Iberian margin: structural constraints on the crustal evolution of the Valencia trough (Western Mediterranean). Tectonophysics 203, 203-218. doi:10.1016/0040-1951(92)90224-T.

Santoyo M.A., García-Jerez A., Francisco Luzón F. (2010): A subsurface stress analysis and its possible relation with seismicity near the Itoiz Reservoir, Navarra, Northern Spain. Tectonophysics 482, 205-215, doi: 10.1016/j.tecto.2009.06.022.

Sinclair, H.D., Gibson, M., Naylor, M., Morris, R.G. (2005): Asymmetric growth of the Pyrenees revealed through measurement and modeling of orogenic fluxes. Am. J. Sci., 305(5), 369-406. doi: 10.2475/ajs.305.5.369.

Secanell, R., Bertil, D., Marin, C., Goula, X., Susagna, T., Tapia, M., Dominique, P., Carbon, D., Fleta, J. (2008): Probabilistic seismic hazard assessment of the Pyrenean region. Journal of Seismology 12, 323-341. doi: 10.1007/s10950-008-9094-2.

Segall, P., Grasso, J., Mossop, A. (1994): Poroelastic stressing and induced seismicity near the Lacq gas field, southwestern France, $J$. geophys. Res. 99, 423-438. doi:10.1029/94JB00989.

Séguret, M., Daignières, M. (1986): Crustal scale balanced cross-sec- 
tions of the Pyrenees; discussion = Coupes balancées à l'échelle de la croûte pour les Pyrénées : discussion. Tectonophysics 129, 303318. doi:10.1016/0040-1951(86)90258-1.

Schlunegger, F., Hinderer, M. (2001): Crustal uplift in the Alps: why the drainage pattern matters. Terra Nova 13, 425-432. doi: 10.1046/j.1365-3121.2001.00374.x.

Souriau, A., Granet, M. (1995): A tomographic study of the lithosphere beneath the Pyrenees from local and teleseismic data, J. geophys. Res. 100, 18 117-18 134. doi:10.1029/95JB01053.

Souriau, A., Pauchet, H. (1998): A new synthesis of Pyrenean seismicity and its tectonic implications. Tectonophysics 290, 221-244. doi: 10.1016/S0040-1951(98)00017-1.

Souriau, A., Sylvander, M., Rigo, A., Fels, J., Douchain, J., Ponsolles, C. (2001): Sismotectonique des Pyrénées; principales contraintes sismologiques. B. Soc. Géol. France 172, 25-39. doi: 10.2113/172.1.25.

Souriau, A., Chevrot, S., Olivera, C. (2008): A new tomographic image of the Pyrenean lithosphere from teleseismic data. Tectonophysics 460, 206-214. doi: 10.1016/j.tecto.2008.08.014.

Stich, D., Martín, R., Morales, J. (2010): Moment tensor inversion for Iberia-Maghreb earthquakes 2005-2008. Tectonophysics 483, 390398. doi: 10.1016/j.tecto.2009.11.006.

Suc, J.-P., Fauquette, S. (2012): The use of pollen floras as a tool to estimate palaeoaltitude of mountains: The Eastern Pyrenees in the Late Neogene, a case study. Palaeogeography, Palaeoclimatology, Palaeoecology 321-322, 41-54. doi: 10.1016/j.palaeo.2012.01.014.

Susagna, T., Roca, A., Goula, X., Batlló, J. (1994): Analysis of Macroseismic andInstrumental Data for the Study of the 19 November 1923 Earthquake in the Aran Valley (Central Pyrenees). Natural Hazards 10, 7-17.

Sylvander, M., Monod, M., Souriau, A., Rigo, A. (2007): Analysis of an earthquake swarm (May 2004) in the French eastern Pyrenees: Towards a new tectonic interpretation of the Saint-Paul-de-Fenouillet earthquake (1996). C. R. Geosciences 339, 75-84. doi: 10.1016/j. crte.2006.11.002.

Sylvander, M., Souriau, A., Rigo, A., Tocheport, A., Toutain, J., Ponsolles, C., Benahmed, S. (2008): The November 2006, ML=5.0 earthquake near Lourdes (France): new evidence for NS extension across the Pyrenees. Geophys. J. Int. 175, 649-664. doi: 10.1111/j.1365-246X.2008.03911.x.

Teixell, A. (1996): The Anso transect of the southern Pyrenees: basement and cover thrust geometries, J. Geol. Soc. London, 153, 301310. doi :10.1144/gsjgs.153.2.0301.

Thibault, C. (1969): Eléments de tectonique dans le bassin de l'Adour. Quaternaria, II, 189-195.

Thomas, G., Pailhé, P. (1984): Traversée des Pyrénées occidentales de Bérenx à Sangüesa., in BRGM (ed.), Excursions géologiques de la chaîne des Pyrénées, A.G.S.Q.
Toutain, J.-P., Muñoz, M., Poitrasson, F., Lienard, A.D. (1999): Springwater chloride ion anomaly prior to a $\mathrm{Ml}=5.2$ Pyrenean earthquake. Earth Planet. Sci. Lett. 149, 113-120. doi:10.1016/ S0012-821X(97)00066-6.

Trong, P.H., Rouland, D. (1971): Mécanisme au foyer du séisme d'Arette, Pyrénéees-Atlantiques, C.R. Acad. Sci. Paris 272, 32493251.

Turu, V., Planas, X. (2005): Inestabilidad de vertientes en los valles del Valira. Datos y dataciones para el establecimiento de una cronología, posibles causas. Andorra y Alt Urgell (Pirineos orientales). VI Simposio Nacional sobre Taludes y Laderas Inestables. Valencia, Abstracts.

Turu, V., Peña, J.L. (2006a): Las terrazas fluviales del sistema SegreValira (Andorra-La Seu d'Urgell-Organyà, Pirineos Orientales) : relación con el glaciarismo y la tectónica activa. In A. Pérez-Alberti, J. López-Bedoya (eds.), Geomorfología yTerritorio : Actas de la IX Reunión Nacional de Geomorfología. Universidad de Santiago de Compostela, 171, 101-112.

Turu, V., Peña, J.L. (2006b): Ensayo de reconstrucción cuaternaria de los valles del Segre y Valira (Andorra-La Seu d'Urgell- Organyà, Pirineos Orientales): morrenas y terrazas fluviales. In A.Y. PérezAlberti, J. López-Bedoya (eds.), Geomorfología y Territorio : Actas de la IX Reunión Nacional de Geomorfología. Universidad de Santiago de Compostela, 171, 113-129.

Vanara, N., Maire, R., Lacroix, J. (1997): La surface carbonatée du massif des Arbailles (Pyrénées Atlantiques): un example de paléoréseau hydrographique néogéne déconnecté par la surrection. Bull. Soc. géol. France 168, 255-65.

Vanara, N. (2000): Le karst des Arbailles. Karstologia Mémoire 8, 320 p.

Vergés, J. (1993): Estudi geológic del vessant sud del Pirineu oriental i central. Evolució cinemàtica en $3 D$. PhD. Thesis. Univ. Barcelona: 203p.

Vergés, J. (1994): Estudio geológico de la vertiente sur del Pirineo oriental y central. Evolución cinemática en 3D. Acta Geológica Hispánica 29, 195-199.

Vergés, J., Millan, H., Roca, E., Muñoz, J., Marzo, M., Cires, J., den Bezemer, T., Zoetemeijer, R., Cloetingh, S. (1995): Evolution of a collisional orogen : Eastern Pyrenees transect and petroleum potential. Mar. Petrol. Geol. 12, 903-916.

Vernant, P., Fadil, A., Mourabit, T., Ouazar, D., Koulali, A., Davila, J. M., Garate, J., McClusky, S., Reilinger, R. (2010): Geodetic constraints on active tectonics of the Western Mediterranean: Implications for the kinematics and dynamics of the Nubia-Eurasia plate boundary zone. J. Geodyn., 49, 123-129. doi: 10.1016/j. jog.2009.10.007.

Vogt, J. (1979): Les tremblements de terre en France. Mem. BRGM 96, Orleans, France: 220 p. 